\title{
Stock Market Booms and Monetary Policy in the Twentieth Century
}

\author{
Michael D. Bordo and David C. Wheelock
}

\begin{abstract}
This article examines the association between stock market booms and monetary policy in the United States and nine other developed countries during the 20th century. The authors find, as was true of the U.S. stock market boom of 1994-2000, that booms typically arose during periods of above-average growth of real output and below-average inflation, suggesting that booms reflected both real macroeconomic phenomena and monetary policy. They find little evidence that booms were fueled by excessive liquidity. Booms often ended within a few months of an increase in inflation and consequent monetary policy tightening. They find few differences across the different monetary policy regimes of the century. (JEL E300, E520, G180, N100, N200)
\end{abstract}

Federal Reserve Bank of St. Louis Review, March/April 2007, 89(2), pp. 91-122.

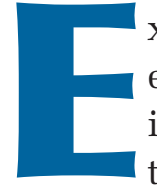

xtended periods of rapidly appreciating equity, housing, and other asset prices in the United States and elsewhere since the mid-1990s have brought increased attention to the effects of monetary policy on asset markets and the appropriate response, if any, of monetary policy to asset price booms. Some economists argue that financial markets are inherently volatile and that market prices often stray from fundamentals, suggesting that policymakers could improve welfare by attempting to deflate asset price booms, especially if sudden declines in asset prices are likely to depress economic activity. Other economists contend that financial markets process information efficiently. These economists tend to believe that policymakers usually cannot determine when assets are mispriced and, hence, that they cannot enhance aggregate welfare by reacting to asset price movements. ${ }^{1}$

The U.S. stock market boom of the late 1990s arose during a period of increased productivity growth, which many observers hailed as evidence of a "New Economy" that justified rapid appreciation of equity prices. The period was also marked by low and stable inflation, which may have contributed to the boom by foreshadowing strong growth of economic activity and corporate profits. Some analysts have argued, however, that the rapid rise in equity prices was simply a manifestation of loose monetary policy that happened to generate asset price inflation rather than consumer price inflation. ${ }^{2}$ The end of the boom did coincide with a tightening of monetary policy. This tightening seems to have been in response to rising consumer price inflation and inflation expecta-

\footnotetext{
1 See Kohn (2006) for a recent comparison of alternative monetary policy strategies in response to asset price booms. See also Bordo and Wheelock (2004).

2 Rapid growth of asset prices amid low consumer price inflation renewed interest in the question of whether monetary policy should target measures of inflation that include asset prices as well as consumer prices. Proponents of broader inflation measures include Goodhart and Hofmann (2000) and Bryan, Cecchetti, and O'Sullivan (2002).
}

Michael D. Bordo is a professor of economics at Rutgers University and an associate of the National Bureau of Economic Research. David C. Wheelock is an assistant vice president and economist at the Federal Reserve Bank of St. Louis. The authors thank Edward Nelson and Rajdeep Sengupta for comments on an earlier draft. Daniel McDonald and Joshua Ulrich provided research assistance.

(C) 2007, The Federal Reserve Bank of St. Louis. Articles may be reprinted, reproduced, published, distributed, displayed, and transmitted in their entirety if copyright notice, author name(s), and full citation are included. Abstracts, synopses, and other derivative works may be made only with prior written permission of the Federal Reserve Bank of St. Louis. 
tions, though some studies conclude that the Fed also sought to contain the booming stock market. ${ }^{3}$

The purpose of this article is to discern whether the patterns of output and productivity growth, inflation, and monetary policy observed during the U.S. boom of the 1990s were similar to those of other stock market booms in the United States and elsewhere during the 20th century. We are especially interested in whether these patterns differed across monetary policy regimes. Monetary neutrality implies that monetary policy should not affect the price of stocks, which are claims on real assets, in the long run. Empirical studies conclude, however, that policy actions affect stock prices in the short run, and many researchers contend that the form of policy rule used by monetary authorities can also affect asset markets over longer horizons. In particular, some argue that use of a monetary rule involving a clearly specified, credible inflation objective could lessen instability in financial markets, though others contend that such rules can promote "imbalances" that may lead to financial instability. This article seeks to identify similarities or differences in the association of monetary policy and stock market booms across different monetary policy environments. In so doing, we hope to gain insight into the role of monetary policy in supporting or ending asset booms. ${ }^{4}$

We construct monthly, real (i.e., inflationadjusted) stock price indices for the United States and nine other countries for which the necessary data are available over most of the 20th century. We then identify extended periods of unusually rapid appreciation in the indices for each country, which we define as booms. Finally, we use a simple event methodology to examine the behavior of important macroeconomic and monetary policy variables during stock market booms, and we

\footnotetext{
3 For contrasting views on whether the Fed adjusted policy in response to the stock market during this period, see Cecchetti (2003), Rigobon and Sack (2003), Hayford and Malliaris (2004), and Meyer (2004).

4 Bordo and Wheelock (2004) investigate the association of nominal U.S. stock prices with output, inflation, and money stock growth over the 19th and 20th centuries. The present article, by contrast, focuses on periods of rapid appreciation of real stock prices and compares the U.S. experience with the experiences of other countries.
}

compare U.S. experiences with those of the other countries in our sample. We find that 20th century stock market booms typically were associated with the business cycle, arising when output (real gross domestic product [GDP]) growth was above average and ending as output growth slowed. We also find that booms tended to arise when consumer price inflation was low and end after a period of monetary policy tightening associated with an actual or threatened rise in inflation. These patterns differ little across time and, therefore, across the different policy regimes in place over the 20th century. Finally, the patterns we observe for U.S. stock market booms also appear broadly similar to those of other countries in our data.

The next section of this article briefly discusses how monetary policy might affect stock prices. We then present information about the stock market booms in our data. Subsequent sections examine the macroeconomic conditions under which 20th century stock market booms occurred in the United States and other countries. The final section summarizes our observations and conclusions.

\section{MONETARY POLICY AND STOCK PRICES}

The basic efficient-markets present-value model posits that stock prices reflect discounted expected future dividends and, hence, that price changes reflect changes in expected dividends and/or the discount rate (proxied by the real interest rate). Because stocks are claims on real assets, monetary neutrality implies that policy should not affect real stock prices in the long run. Monetary policy actions might affect stock prices over shorter horizons, however, by altering the path of expected dividends, the discount rate, or the equity premium. ${ }^{5}$ Early models of the effects of monetary policy on asset prices focused on the impact of changes in liquidity on the demand

\footnotetext{
5 The equity premium is the excess return for holding equities over short-term debt securities, which in the United States averaged about 3 percent over the 19th and 20th centuries. The premium provides compensation for uncertainty about the timing and magnitude of future cash flows associated with ownership of equities rather than fixed-income securities.
} 
for various assets that comprise the portfolio of the private sector. Policy actions that increase liquidity cause asset prices to rise and returns to fall as households adjust their portfolios in response to an increase in central bank liabilities. Other models focused on the impact of policy on the cost of capital and, hence, the expected growth rates of corporate dividends or earnings. ${ }^{6}$

Several studies have found evidence that monetary policy actions affect stock prices in the short run. Bernanke and Kuttner (2005), for example, estimate that during 1989-2002 an unanticipated 25-basis-point increase in the Federal Reserve's target for the federal funds rate produced a 1 percent decline in equity prices. Further, they find that the impact of unanticipated monetary policy actions on stock prices occurred mainly through their impact on expected future dividends and excess returns (i.e., the equity premium) rather than the real interest rate.

Although monetary policy actions appear to affect stock prices in the short run, many economists contend that the form of policy rule used by monetary authorities can affect the performance of asset markets over longer horizons. Some economists argue that monetary policies that result in persistent or highly variable inflation destabilize financial markets (e.g., Schwartz, 1995). Rules that stabilize the price level, however, are commonly thought to lessen the chance of asset price bubbles (e.g., Woodford, 2003). Some economists argue, however, that a commitment to low inflation can foster imbalances that lead to asset price bubbles by generating overly optimistic expectations of future economic growth (e.g., Borio and Lowe, 2002). Federal Reserve Chairman Alan Greenspan made this claim at a Federal Open Market Committee (FOMC) meeting in 1996:

We have very great difficulty in monetary policy when we confront stock market bubbles. That is because, to the extent that we are successful in keeping product price inflation down, history tells us that price-earnings ratios under those conditions go through the roof. What is really needed to keep stock market

${ }^{6}$ See Bordo and Wheelock (2004) for additional discussion and references. bubbles from occurring is a lot of product price inflation, which historically has tended to undercut stock markets almost everywhere. There is a clear tradeoff. If monetary policy succeeds in one, it fails in the other. (FOMC, September 24, 1996, pp. 30-31)

Historically, U.S. stock market returns have been negatively correlated with inflation (Fama and Schwert, 1977). Goodfriend (2003) argues that prior to the 1980s, monetary policy was an important source of both macroeconomic and financial market instability, which could explain the negative relationship between stock returns and inflation. An increase in inflation would tend to depress stock returns because long-term interest rates would rise in response to higher expected inflation and tighter monetary policy and because tighter policy would also slow economic activity and thereby reduce current and future corporate earnings. A reversal of policy in response to a weak economy and lower inflation would tend to reduce interest rates and boost stock returns.

Goodfriend (2003) contends that asset price movements are less likely to be correlated with policy actions if monetary policymakers are firmly committed to maintaining price stability. Under such a regime, he argues, long-term interest rates will be more firmly anchored and real activity, corporate profits, and real interest rates will exhibit less cyclical variability. Hence, under a policy rule that maintains a stable price level, movements in asset prices are likely to be less correlated with specific monetary policy actions. One objective of this article is to determine whether stock market booms in the United States and other countries typically have been associated with low inflation, especially with changes in monetary policy that foster price stability, and whether we can observe differences in the relationships over time that might be associated with differences in policy regimes.

\section{STOCK MARKET BOOMS}

There is, of course, no precise definition of an asset boom, and researchers have imposed a number of filters to identify specific episodes that 
Table 1

\section{Stock Market Booms}

\begin{tabular}{|c|c|c|c|c|}
\hline Country & $\begin{array}{c}\text { Boom start: } \\
\text { local market minimum }\end{array}$ & $\begin{array}{l}\text { Boom end: } \\
\text { local market peak }\end{array}$ & $\begin{array}{c}\text { Average annual } \\
\% \text { change from } \\
\text { month after trough } \\
\text { to peak }\end{array}$ & $\begin{array}{c}\text { When prior } \\
\text { 25-month peak } \\
\text { surpassed }\end{array}$ \\
\hline \multirow[t]{8}{*}{ Australia } & Dec. 1920 & Feb. 1929 & 10.7 & July 1921 \\
\hline & Sept. 1930 & Mar. 1937 & 17.8 & Oct. 1934 \\
\hline & July 1956 & July 1960 & 15.8 & Aug. 1957 \\
\hline & Oct. 1966 & Dec. 1969 & 21.8 & Oct. 1967 \\
\hline & Aug. 1977 & Nov. 1980 & 21.9 & Sept. 1979 \\
\hline & July 1982 & Sept. 1987 & 25.2 & Mar. 1986 \\
\hline & Dec. 1990 & Jan. 1994 & 18.9 & Oct. 1993 \\
\hline & Aug. 1998 & June 2000 & 13.4 & Jan. 1999 \\
\hline \multirow[t]{7}{*}{ Canada } & Dec. 1920 & Sept. 1929 & 17.4 & $\mathrm{n} / \mathrm{a}$ \\
\hline & June 1932 & Mar. 1937 & 28.0 & $\mathrm{n} / \mathrm{a}$ \\
\hline & Oct. 1953 & July 1956 & 24.6 & July 1954 \\
\hline & Oct. 1977 & Nov. 1980 & 22.1 & $\mathrm{n} / \mathrm{a}$ \\
\hline & July 1984 & July 1987 & 17.9 & July 1985 \\
\hline & Jan. 1995 & Apr. 1998 & 19.2 & Nov. 1995 \\
\hline & Aug. 1998 & Aug. 2000 & 34.7 & Dec. 1999 \\
\hline \multirow[t]{6}{*}{ France } & Nov. 1920 & July 1924 & 20.9 & $\mathrm{n} / \mathrm{a}$ \\
\hline & Nov. 1926 & Feb. 1929 & 40.4 & Dec. 1927 \\
\hline & Dec. 1950 & Apr. 1955 & 28.4 & $\mathrm{n} / \mathrm{a}$ \\
\hline & Aug. 1958 & Apr. 1962 & 20 & July 1960 \\
\hline & June 1981 & Apr. 1987 & 24.4 & Jan. 1985 \\
\hline & Feb. 1995 & Aug. 2000 & 23.6 & Jan. 1997 \\
\hline \multirow[t]{3}{*}{ Germany } & June 1957 & Sept. 1960 & 43.6 & Aug. 1958 \\
\hline & Aug. 1982 & Apr. 1986 & 31.8 & July 1983 \\
\hline & Mar. 1995 & Feb. 2000 & 23.9 & Sept. 1996 \\
\hline \multirow[t]{6}{*}{ Italy } & May 1932 & July 1935 & 27.5 & $\mathrm{n} / \mathrm{a}$ \\
\hline & July 1950 & Sept. 1955 & 18.5 & Aug. 1952 \\
\hline & June 1958 & Aug. 1960 & 56.4 & Oct. 1958 \\
\hline & Dec. 1977 & May 1981 & 35.0 & $\mathrm{n} / \mathrm{a}$ \\
\hline & Dec. 1982 & Aug. 1986 & 38.2 & Mar. 1986 \\
\hline & Nov. 1995 & Feb. 2000 & 33.6 & July 1997 \\
\hline
\end{tabular}

NOTE: *Market decline ended less than 12 months after boom peak; ${ }^{a}$ comparison Jan. 1915-Dec. 1940; ${ }^{b}$ comparison Jan. 1947-Dec. 2004; ${ }^{\mathrm{c}}$ Comparison Feb. 1920-Dec. 1940; ${ }^{\mathrm{d}}$ Comparison Jan. 1920-Dec. 1939; ${ }^{\mathrm{e}}$ comparison Jan. 1950-Dec. 2004; ${ }^{\mathrm{f}}$ comparison Feb. 1921-Dec. 1938;

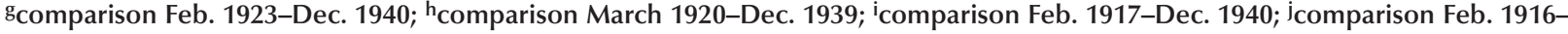

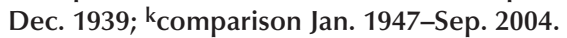




\begin{tabular}{|c|c|c|c|c|}
\hline $\begin{array}{c}\text { Months duration } \\
\text { after prior peak } \\
\text { surpassed }\end{array}$ & $\begin{array}{c}\text { Average annual } \\
\% \text { change from } \\
\text { month after } \\
\text { prior peak }\end{array}$ & $\begin{array}{c}\text { Comparison } \\
\text { average annual } \\
\% \text { change } \\
\text { during period }\end{array}$ & $\begin{array}{l}\text { Percent decline } \\
12 \text { months } \\
\text { after peak }\end{array}$ & $\begin{array}{l}\text { Percent decline } \\
\text { to next minimum }\end{array}$ \\
\hline 91 & 9.1 & $3.6^{\mathrm{a}}$ & -20.1 & -41.0 \\
\hline 30 & 13.7 & 3.6 & -12.2 & -31.6 \\
\hline 35 & 15.9 & $2.4^{b}$ & -11.6 & $-20.2^{*}$ \\
\hline 26 & 17.5 & 2.4 & -24.8 & -42.2 \\
\hline 14 & 32.1 & 2.4 & -27.2 & -47.2 \\
\hline 18 & 39.3 & 2.4 & -35.8 & $-46.3^{*}$ \\
\hline 3 & 36.9 & 2.4 & -23.8 & -23.8 \\
\hline 18 & 6.5 & 2.4 & -0.8 & -23.8 \\
\hline $\mathrm{n} / \mathrm{a}$ & $\mathrm{n} / \mathrm{a}$ & $3.7^{\mathrm{c}}$ & -37.5 & -75.1 \\
\hline $\mathrm{n} / \mathrm{a}$ & $\mathrm{n} / \mathrm{a}$ & 3.7 & -35.6 & -35.6 \\
\hline 25 & 23.5 & $3.4^{b}$ & -9.2 & -32.4 \\
\hline $\mathrm{n} / \mathrm{a}$ & $\mathrm{n} / \mathrm{a}$ & 3.4 & -25.2 & -52.5 \\
\hline 24 & 15.3 & 3.4 & -18.5 & $-26.7^{*}$ \\
\hline 29 & 20.1 & 3.4 & -10.0 & $-28.2^{*}$ \\
\hline 8 & 42.0 & 3.4 & -36.0 & -43.6 \\
\hline $\mathrm{n} / \mathrm{a}$ & $\mathrm{n} / \mathrm{a}$ & $2.5^{\mathrm{d}}$ & -16.1 & -34.7 \\
\hline 14 & 37.9 & 2.5 & -12.0 & -57.0 \\
\hline $\mathrm{n} / \mathrm{a}$ & $\mathrm{n} / \mathrm{a}$ & $2.8^{b}$ & -17.4 & $-11.1^{*}$ \\
\hline 21 & 14.3 & 2.8 & -18.7 & -54.1 \\
\hline 25 & 36.2 & 2.8 & -32.8 & -45.0 \\
\hline 43 & 26.8 & 2.8 & -29.5 & -60.1 \\
\hline 25 & 54.1 & $6.0^{\mathrm{e}}$ & -24.0 & -49.3 \\
\hline 33 & 28.8 & 6.0 & -18.4 & -44.7 \\
\hline 41 & 27.8 & 6.0 & -25.4 & -69.9 \\
\hline $\mathrm{n} / \mathrm{a}$ & $\mathrm{n} / \mathrm{a}$ & $0.4^{f}$ & -13.4 & $-20.0^{*}$ \\
\hline 37 & 22.7 & $3.1^{\mathrm{e}}$ & -16.6 & $-22.2^{*}$ \\
\hline 23 & 58.7 & 3.1 & -17.6 & -17.6 \\
\hline $\mathrm{n} / \mathrm{a}$ & $\mathrm{n} / \mathrm{a}$ & 3.1 & -46.8 & -54.1 \\
\hline 5 & 34.3 & 3.1 & -26.7 & -47.9 \\
\hline 31 & 34.9 & 3.1 & -18.8 & -56.5 \\
\hline
\end{tabular}


Table 1, cont'd

\begin{tabular}{|c|c|c|c|c|}
\hline Country & $\begin{array}{c}\text { Boom start: } \\
\text { local market minimum }\end{array}$ & $\begin{array}{c}\text { Boom end: } \\
\text { local market peak }\end{array}$ & $\begin{array}{c}\text { Average annual } \\
\% \text { change from } \\
\text { month after trough } \\
\text { to peak }\end{array}$ & $\begin{array}{c}\text { When prior } \\
\text { 25-month peak } \\
\text { surpassed }\end{array}$ \\
\hline \multirow[t]{4}{*}{ Japan } & Oct. 1930 & Feb. 1934 & 28.6 & Feb. 1932 \\
\hline & Jan. 1950 & Jan. 1953 & 54.3 & Jan. 1952 \\
\hline & Dec. 1957 & June 1961 & 36.3 & Oct. 1958 \\
\hline & Sept. 1982 & Dec. 1989 & 23.9 & Mar. 1983 \\
\hline \multirow[t]{6}{*}{ Netherlands } & July 1924 & Feb. 1929 & 10.9 & Jan. 1926 \\
\hline & June 1932 & Mar. 1937 & 26.6 & $\mathrm{n} / \mathrm{a}$ \\
\hline & Apr. 1952 & June 1957 & 20.3 & Nov. 1954 \\
\hline & Dec. 1957 & Mar. 1961 & 22.2 & May 1959 \\
\hline & Sep. 1981 & July 1987 & 22.0 & Mar. 1983 \\
\hline & Jan. 1991 & Aug. 2000 & 17.4 & June 1993 \\
\hline \multirow[t]{5}{*}{ Sweden } & Mar. 1922 & July 1929 & 16.9 & $\mathrm{n} / \mathrm{a}$ \\
\hline & May 1932 & Mar. 1937 & 23.2 & $\mathrm{n} / \mathrm{a}$ \\
\hline & Mar. 1958 & Aug. 1961 & 15.1 & Aug. 1958 \\
\hline & Sept. 1980 & Mar. 1984 & 36.8 & May 1981 \\
\hline & Sept. 1992 & Feb. 2000 & 31.4 & Sept. 1995 \\
\hline \multirow[t]{5}{*}{ United Kingdom } & June 1932 & Dec. 1936 & 15.4 & Feb. 1936 \\
\hline & June 1952 & July 1955 & 20.0 & July 1954 \\
\hline & Feb. 1958 & Apr. 1961 & 25.4 & Dec. 1958 \\
\hline & Sept. 1981 & July 1987 & 21.3 & Oct. 1982 \\
\hline & June 1994 & Dec. 1999 & 12.6 & Apr. 1996 \\
\hline \multirow[t]{6}{*}{ United States } & Oct. 1923 & Sept. 1929 & 23.7 & Dec. 1924 \\
\hline & Mar. 1935 & Feb. 1937 & 39.7 & Oct. 1935 \\
\hline & Sept. 1953 & Apr. 1956 & 28.8 & Mar. 1954 \\
\hline & June 1962 & Jan. 1966 & 13.3 & Dec. 1963 \\
\hline & July 1984 & Aug. 1987 & 22.9 & Feb. 1985 \\
\hline & Apr. 1994 & Aug. 2000 & 17.1 & Mar. 1995 \\
\hline
\end{tabular}




\begin{tabular}{|c|c|c|c|c|}
\hline $\begin{array}{l}\text { Months duration } \\
\text { after prior peak } \\
\text { surpassed }\end{array}$ & $\begin{array}{c}\text { Average annual } \\
\% \text { change from } \\
\text { month after } \\
\text { prior peak }\end{array}$ & $\begin{array}{c}\text { Comparison } \\
\text { average annual } \\
\% \text { change } \\
\text { during period }\end{array}$ & $\begin{array}{l}\text { Percent decline } \\
12 \text { months } \\
\text { after peak }\end{array}$ & $\begin{array}{l}\text { Percent decline } \\
\text { to next minimum }\end{array}$ \\
\hline 24 & 26.1 & $1.8^{\mathrm{g}}$ & -12.0 & -16.6 \\
\hline 12 & 93.1 & $6.9^{\mathrm{e}}$ & -30.0 & -36.4 \\
\hline 32 & 38.7 & 6.9 & -23.0 & -52.7 \\
\hline 81 & 22.5 & 6.9 & -41.0 & $-47.6^{*}$ \\
\hline 36 & 6.1 & $-1.8^{\mathrm{h}}$ & -15.7 & -71.8 \\
\hline $\mathrm{n} / \mathrm{a}$ & $\mathrm{n} / \mathrm{a}$ & -1.8 & -18.2 & -31.5 \\
\hline 31 & 15.4 & $4.1^{\mathrm{b}}$ & -19.8 & $-32.1^{*}$ \\
\hline 22 & 15.0 & 4.1 & -10.5 & -31.2 \\
\hline 52 & 20.1 & 4.1 & -17.2 & $-36.7^{*}$ \\
\hline 74 & 19.6 & 4.1 & -26.8 & -65.4 \\
\hline $\mathrm{n} / \mathrm{a}$ & $\mathrm{n} / \mathrm{a}$ & $-1.8^{\mathrm{i}}$ & -13.1 & -73.3 \\
\hline $\mathrm{n} / \mathrm{a}$ & $\mathrm{n} / \mathrm{a}$ & -1.8 & -12.2 & -12.2 \\
\hline 36 & 13 & $5.7^{b}$ & -15.3 & -20.2 \\
\hline 34 & 34.7 & 5.7 & -24.6 & -29.3 \\
\hline 53 & 30.6 & 5.7 & -31.2 & -67.2 \\
\hline 10 & 5.4 & $-0.4^{j}$ & -23.6 & -44.2 \\
\hline 12 & 16.4 & $2.8^{b}$ & -17.3 & -31.4 \\
\hline 28 & 19.6 & 2.8 & -17.8 & -31.0 \\
\hline 57 & 21.5 & 2.8 & -23.4 & $-34.8^{*}$ \\
\hline 44 & 12.7 & 2.8 & -10.6 & -50.2 \\
\hline 57 & 24.4 & $2.4^{\mathrm{a}}$ & -30.1 & -80.6 \\
\hline 16 & 30.2 & 2.4 & -39.0 & -45.8 \\
\hline 25 & 29.3 & $4.4^{\mathrm{k}}$ & -9.6 & -20.1 \\
\hline 25 & 10.3 & 4.4 & -12.5 & $-20.1^{*}$ \\
\hline 30 & 21.6 & 4.4 & -22.3 & $-27.5^{*}$ \\
\hline 64 & 18.7 & 4.4 & -22.8 & -46.8 \\
\hline
\end{tabular}


they then define as booms. We adapt the methodology of Pagan and Sossounov (2003) to identify sustained periods of rising real stock prices in the United States and nine other developed countries (Australia, Canada, France, Germany, Italy, Japan, the Netherlands, Sweden, and the United Kingdom). ${ }^{7}$ First, we calculate a monthly index of real stock prices for each country by deflating a nominal stock price index by a consumer price index. We list our data and sources in the appendix. Next, we identify real stock price index peaks and troughs within rolling, 25-month windows. We require that peaks and troughs alternate, and so eliminate all but the highest maximum that occurred before a subsequent trough and all but the lowest minimum that occurred before a subsequent peak. We classify as booms all periods of at least three years from trough to peak with an average annual rate of increase in the real stock price index of at least 10 percent. We also classify as booms a few episodes of exceptional real stock price appreciation that were shorter than three years. ${ }^{8}$

Table 1 lists the episodes we define as booms for each country in our sample. For each boom, we include information about the average annual percentage increase in the market index from the market trough to its peak. Because several booms began as recoveries from market declines, we also note when the real stock price index surpassed its prior 25-month peak and report the average annual percentage increase in the index after that date.

For comparison, Table 1 also reports information about long-run average annual rates of change in the real stock price index for each country. For example, the U.S. real stock price index increased at an average annual rate of 2.4 percent during 1915-40 and 4.4 percent during 1947-2004. Thus, the periods we define as booms were characterized

\footnotetext{
7 We selected our sample countries based on the availability of historical data on a stock market index and key macroeconomic series, which obviously gives rise to possible sample selection bias. We are unsure of the extent to which our findings would differ if our sample included recently developed or emerging market economies.

8 Helbling and Terrones (2004) use a similar procedure to identify booms and busts. Specifically, they identify turning points in the log-level of real equity prices over five-quarter windows and define booms (busts) as the largest one-fourth of all price increases (declines).
}

by rates of appreciation that were substantially higher than long-run averages. Finally, Table 1 also includes information about the extent to which the real stock price index declined during the 12 months following a market peak and from the market peak to the next market trough. Almost all booms were followed by real declines of at least 10 percent within 12 months. Not all booms ended with a spectacular crash, however, and the lengths and sizes of market declines after booms varied widely.

Cross-country comparisons of real stock price index growth rates are problematic because of differences in the composition of the stock market indices of individual countries. For the interwar period, cross-country comparisons are further complicated by differences across countries in (i) the dates when monthly data on a nominal stock price index and inflation are first available and (ii) the nature and the availability of stock price data for the late 1930s associated with when countries became involved in World War II.

For the post-World War II period, we report average growth rates for 1947-2004 for all countries in the sample except Germany, Italy, and Japan, for which we report growth rates over 1950-2004. The real stock price indices for these three countries exhibit rapid growth during the 1950s compared with average growth rates for subsequent decades. Among the other sample countries, we note considerable variation in average real stock price growth rates, ranging from 2.4 percent for Australia to 5.7 percent for Sweden. Again, however, such long-run cross-country comparisons are problematic because the performance of stock markets varied considerably over time within countries, as well as because of differences in the coverage of industries and firms in the stock market indices of individual countries.

Not surprisingly, we find considerable coincidence in the occurrence of stock market booms across sample countries. For example, most countries experienced a substantial increase in real stock prices during the 1920 s and a market peak in 1929. Several countries also had booms in the mid-1930s as their economies climbed out of the Great Depression. More recently, most countries 


\section{Figure 1}

\section{Real GDP Growth Relative to Its Long-Run Average: Post-1970 Booms}

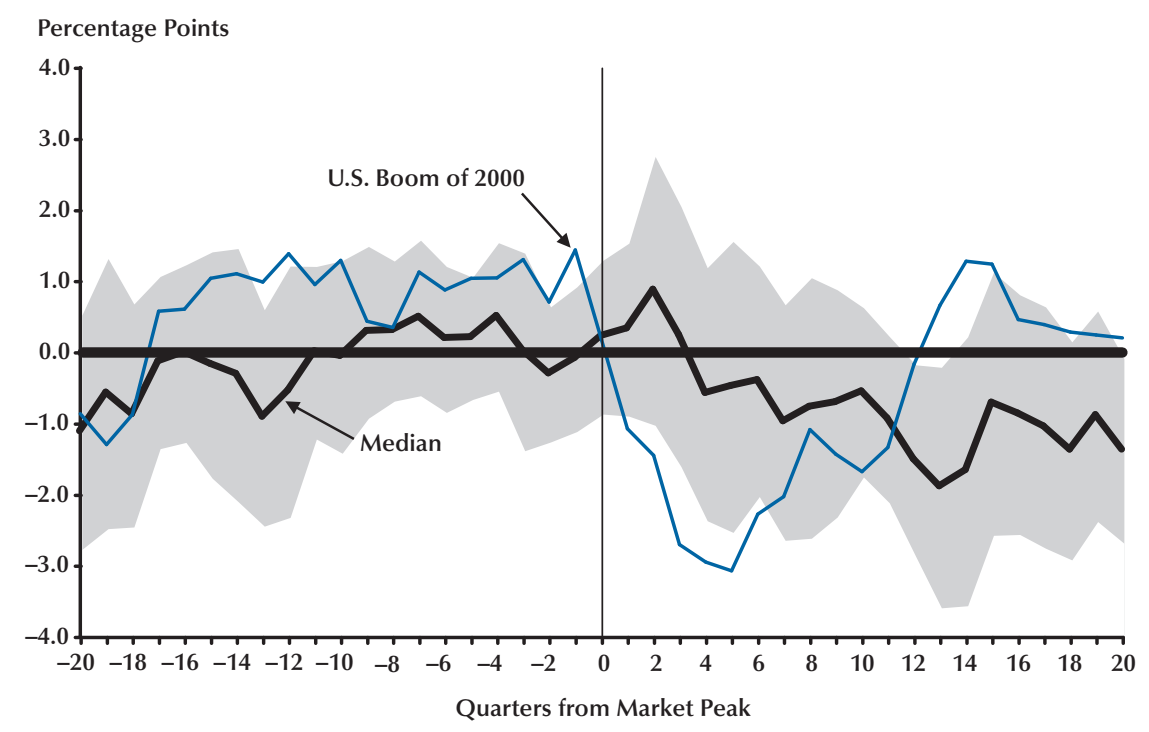

NOTE: The shaded area comprises the median \pm the mean absolute deviation.

in our sample had booms in the 1980s and again in the 1990s. Several countries experienced a market peak within a few months of the U.S. peak in August 1987; and, among our sample, only Japan failed to experience a stock market boom in the 1990s, leading to a peak in 1999 or $2000 .^{9}$

\section{THE U.S. STOCK MARKET BOOM OF 1994-2000}

This article seeks to discern whether patterns observed during the U.S. stock market boom of the 1990s were similar to those observed during prior booms in the United States and other countries. U.S. stock prices rose rapidly during the second half of the 1990s, which many analysts attributed to advances in information-processing technology and increased productivity growth. Both current U.S. output (GDP) and productivity

9 See Bordo and Wheelock (2006) for further evidence on the coincidence of stock market booms and correlation of market returns across countries during the 20th century. See also Goetzmann, Li, and Rouwenhorst (2001). growth were high during these years, whereas inflation was low.

Figure 1 plots data on U.S. real GDP growth relative to its long-run average during the 20 quarters before and after the peak in real stock prices in the third quarter of 2000 (quarter " 0 ”). Real GDP growth exceeded its long-run average by approximately 1 percentage point during the 17 quarters preceding 2000:Q3, then declined sharply as the U.S. economy entered a recession in 2000:Q4. Figure 1 also plots the median growth rates of real GDP (relative to its long-run average) during market peak quarters and in the 20 quarters before and after market peaks across all post-1970 stock market booms among our sample countries, including the U.S. boom of 1994-2000. ${ }^{10}$ Across all booms, median output growth was much closer to its longrun average than U.S. output growth was during the 1994-2000 boom. The decline in output after the "typical" market peak also began later and was much less steep than was experienced after

${ }^{10}$ We define long-run average GDP growth as the average annual rate during 1960-2001. 
Figure 2

Labor Productivity Growth Relative to Its Long-Run Average: Post-1970 Booms

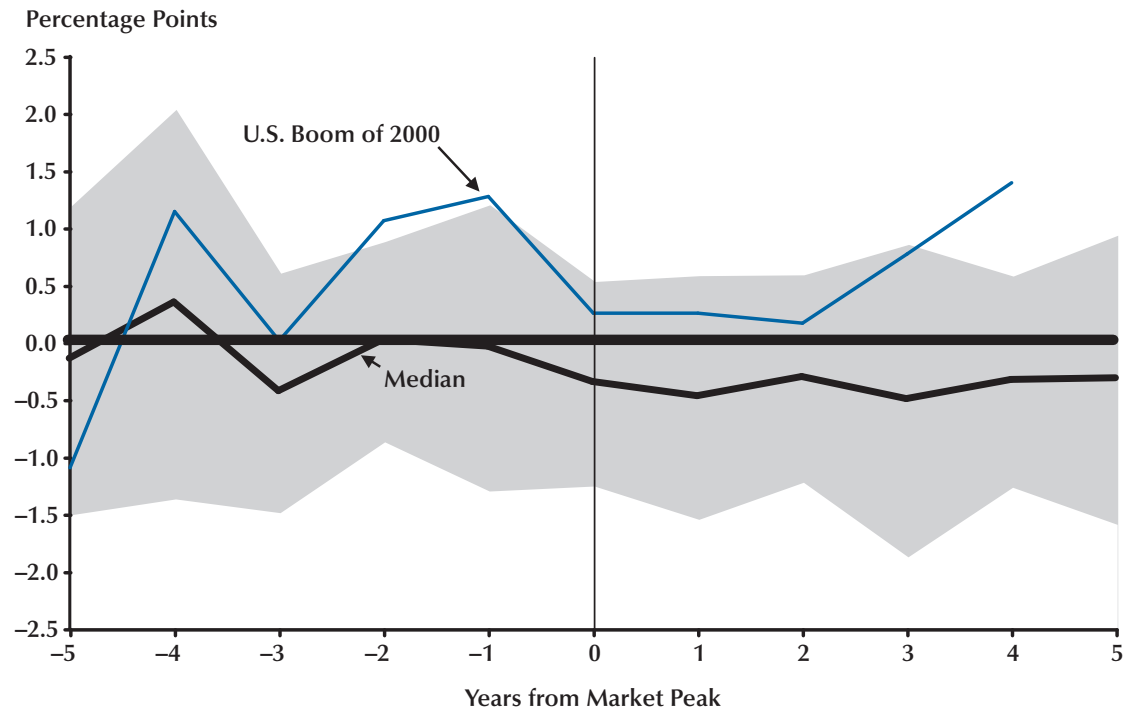

NOTE: The shaded area comprises the median \pm the mean absolute deviation.

Figure 3

Inflation Relative to Its Long-Run Average: Post-1970 Booms

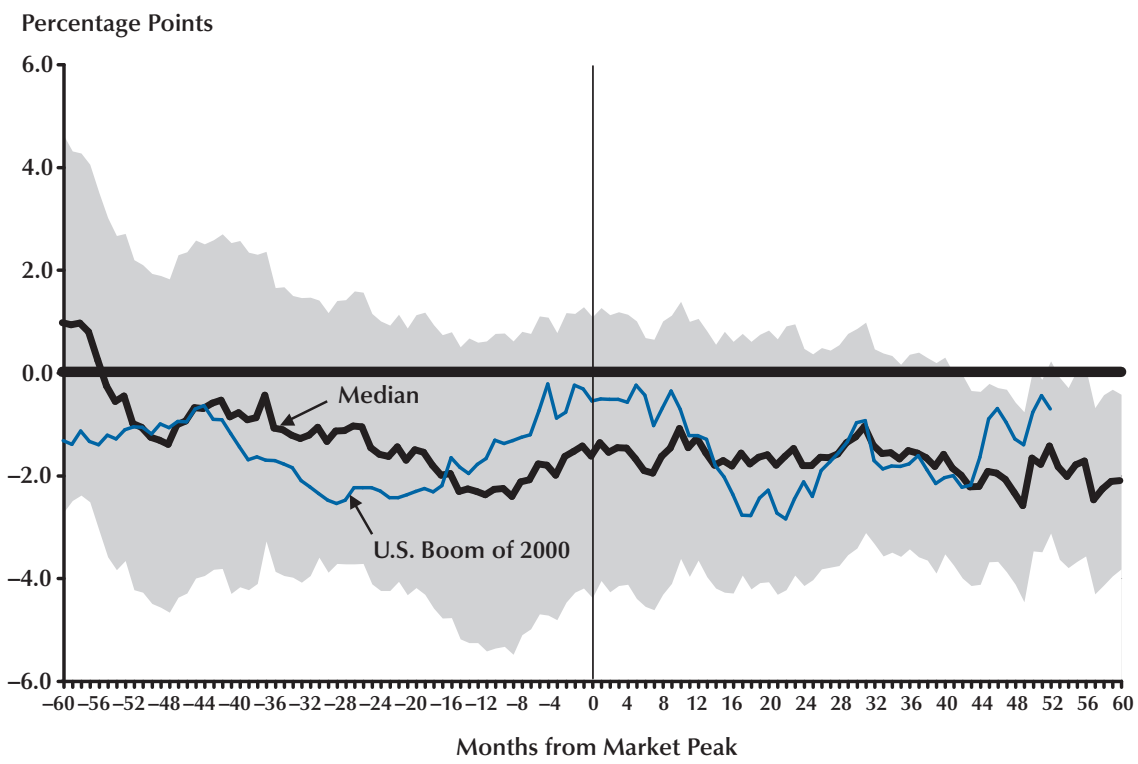

NOTE: The shaded area comprises the median \pm the mean absolute deviation. 
the U.S. stock market peak in 2000:Q3. Figure 1 also displays the mean absolute deviation of real GDP growth (relative to its long-run average) in each quarter across all post-1970 booms. Real GDP growth varied widely during post-1970 booms, and even more so in the quarters after market peaks. $^{11}$

Market analysts frequently attributed the stock market boom of the late 1990s to advances in information technology and an increase in productivity growth that seemed to justify expectations of elevated corporate profits and dividends. Figure 2 plots data on labor productivity growth during the U.S. boom of 1994-2000 and the median across all post-1970 stock market booms. ${ }^{12}$

Whereas U.S. labor productivity growth exceeded its long-run average during four of five years between 1996 and 2000, across all booms, median productivity growth hovered near its long-run average. ${ }^{13}$ Hence, in occurring during a period of above-average productivity growth, the U.S. boom of 1994-2000 was somewhat unusual among recent stock market booms.

While output and productivity growth were both unusually rapid during the U.S. stock market boom of the late 1990s, inflation was unusually low. Consumer price inflation (CPI) hovered between 2.5 and 3 percent from 1992 to 1996, then held below 2 percent from late 1997 to early 1999.

Figure 3 plots monthly data on CPI inflation (relative to its long-run average) during the U.S. boom of 1994-2000, as well as the median across all post-1970 booms. ${ }^{14}$ The figure shows that inflation was below its long-run average throughout the 60 months preceding the August 2000 peak in U.S. real stock prices. Further, the figure shows

\footnotetext{
${ }^{11}$ For example, several countries had stock market booms that coincided with the U.S. boom of 1994-2000. Among them, Australia, Canada, Sweden, and the United Kingdom experienced real GDP growth rates that were consistently higher than their long-run averages; but France, Germany, and Italy had growth rates that were near or below average.

${ }^{12}$ Throughout the paper, for all figures plotting annual data, we define the market peak year "0" as the year prior to the actual peak if the peak occurred in the first half of a year.

${ }^{13}$ Here we define the long-run average productivity growth rate as the average annual growth rate for 1970-2004.

${ }^{14}$ Here we define the long-run average inflation rate as the average rate during 1947-2004.
}

a decline in the inflation rate that occurred in 1997 and early 1998 (months "44" to "29") and an increase during 1999 and the first half of 2000 (approximately the last 20 months of the boom period). Across all post-1970 booms, median inflation was below average and declining until some 12 months before a stock market peak month, when inflation began to rise. Thus, both the U.S. stock market boom of 1994-2000 and the "typical" post-1970 boom arose when inflation was below average and ended after several months of rising inflation.

The U.S. stock market boom of 1994-2000 attracted considerable attention from Federal Reserve officials and other policymakers. Fed officials feared that rapid gains in stock market wealth would cause rapid growth in spending and inflation, but officials were perhaps even more concerned that a sudden decline in the market could lead to a recession. ${ }^{15}$ Policymakers were uncertain about how to respond to the booming stock market, while financial markets were acutely sensitive to any statements or actions by the Fed that signaled possible changes in the direction of policy. Although the Fed was becoming increasingly transparent about its policies, it neither specified an inflation objective nor explained how it might react to the booming stock market.

In December 1996, Federal Reserve Chairman Greenspan made his famous "irrational exuberance" speech, in which he wondered publicly how to determine when equity prices are too high in relation to fundamentals (Greenspan, 1996). Stock prices fell briefly after the Chairman's speech on fears that the Fed would tighten monetary policy or take other actions to slow the growth of stock prices. Indeed, at an FOMC meeting in February 1997, Greenspan suggested that the Fed might want to tighten policy in response to rising stock prices. He argued that the prevailing level of equity prices, along with unusually narrow interest rate credit spreads, "suggest[s] that product prices alone should not be the sole criterion [for conducting monetary policy] if we are going to maintain

\footnotetext{
${ }^{15}$ See Meyer (2004) for an interesting account of Federal Reserve policymaking during this period.
} 


\section{Figure 4}

\section{Short-Term Interest Rate Relative to Its Rate in Peak Month: Post-1970 Booms}

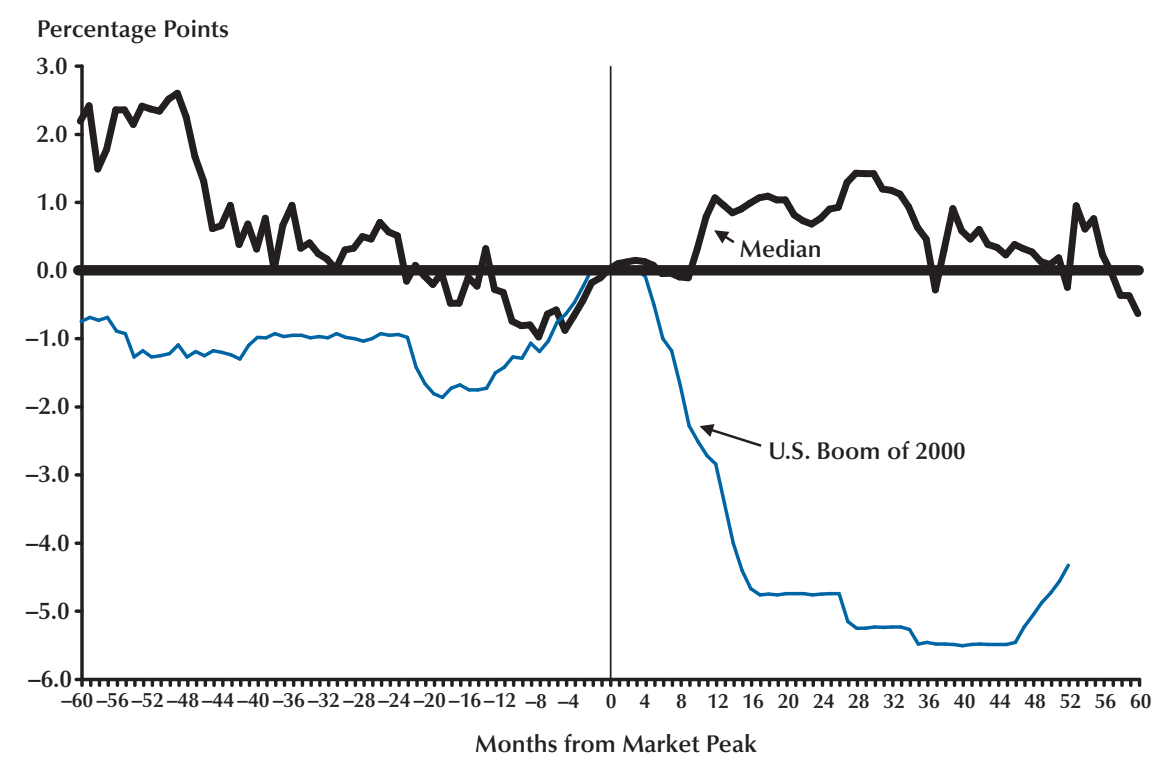

a stable, viable financial system whose fundamental goal...is the attainment of maximum sustainable economic growth" (FOMC, February 4-5, 1997, p. 103).

The FOMC increased its federal funds rate target by 25 basis points in March 1997, but then left the target unchanged over the remainder of the year. Inflation was falling, which puzzled Fed officials who struggled to understand the decline amid rapid economic growth and falling unemployment. ${ }^{16}$ Chairman Greenspan was an early proponent of the view that advances in information processing technology had increased the potential growth rate of output, but most Fed officials and staff were skeptical. ${ }^{17}$ Despite their misgivings about the stock market, however, Fed officials chose not to raise their funds rate target as long as inflation continued to fall. Of course, in not cutting their target, Fed officials permitted the (ex post) real funds rate to rise as the inflation rate fell.

\footnotetext{
${ }^{16}$ Meyer (2004, pp. 79-80).

${ }^{17}$ Meyer (2004, pp. 80-84, 123-25).
}

Figure 4 plots data on the federal funds rate during the U.S. stock market boom of 1994-2000, and the median level of short-term interest rates across all post-1970 booms in our dataset. ${ }^{18}$ Both the funds rate and the median are shown relative to their levels in the months of stock market peaks (month "0"). Figure 5 plots the level of the real interest rate, defined as the nominal short-term interest rate minus the trailing year-over-year inflation rate, during the U.S. stock market boom of 1994-2000 and the median level across all booms. Finally, Figure 6 plots the spread between the yield on long-term Treasury securities and the short-term interest rate for boom periods. The real interest rate and the term spread are two measures that economists often monitor to gauge the stance of monetary policy.

Figures 5 and 6 show that the real funds rate rose and the term spread fell during 1997 (months “-43" to "-32"), and, hence, by these measures,

\footnotetext{
${ }^{18}$ For countries for which data are available, we use an overnight interest rate similar to the U.S. federal funds rate. Otherwise, we use another short-term money market interest rate. See the appendix for details.
} 


\section{Figure 5}

\section{Real Interest Rate: Post-1970 Booms}

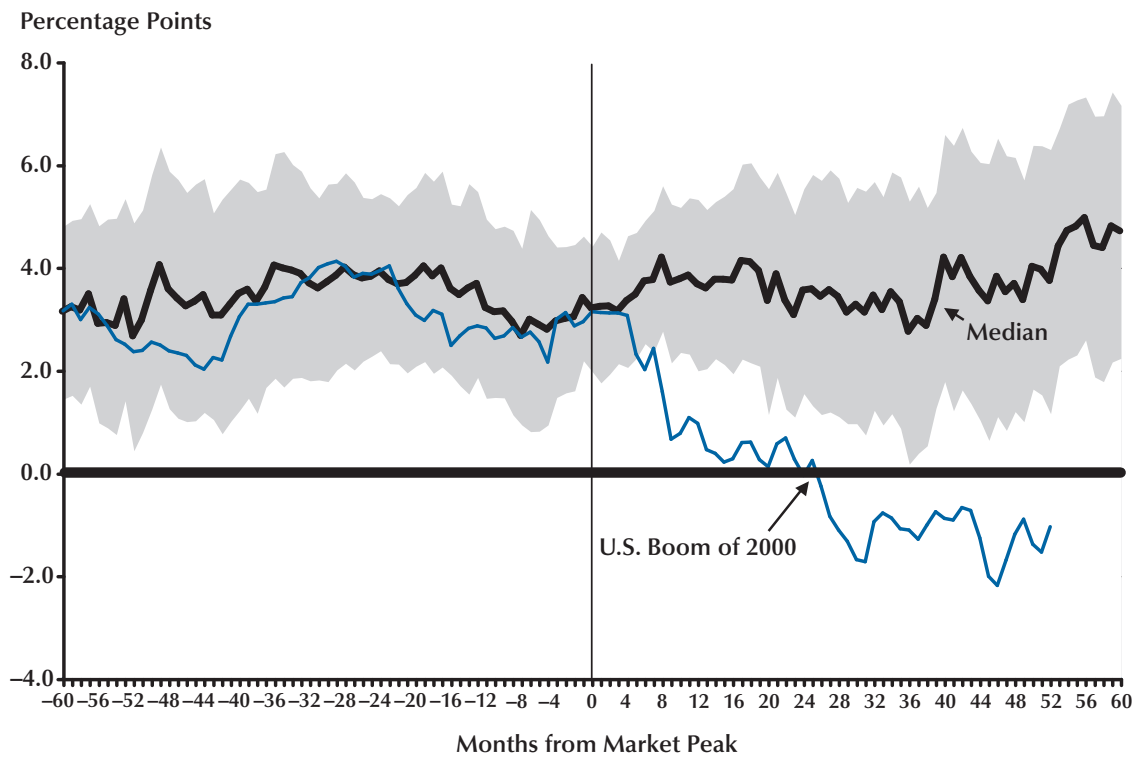

NOTE: The shaded area comprises the median \pm the mean absolute deviation.

Figure 6

Interest Rate Term Spread: Post-1970 Booms

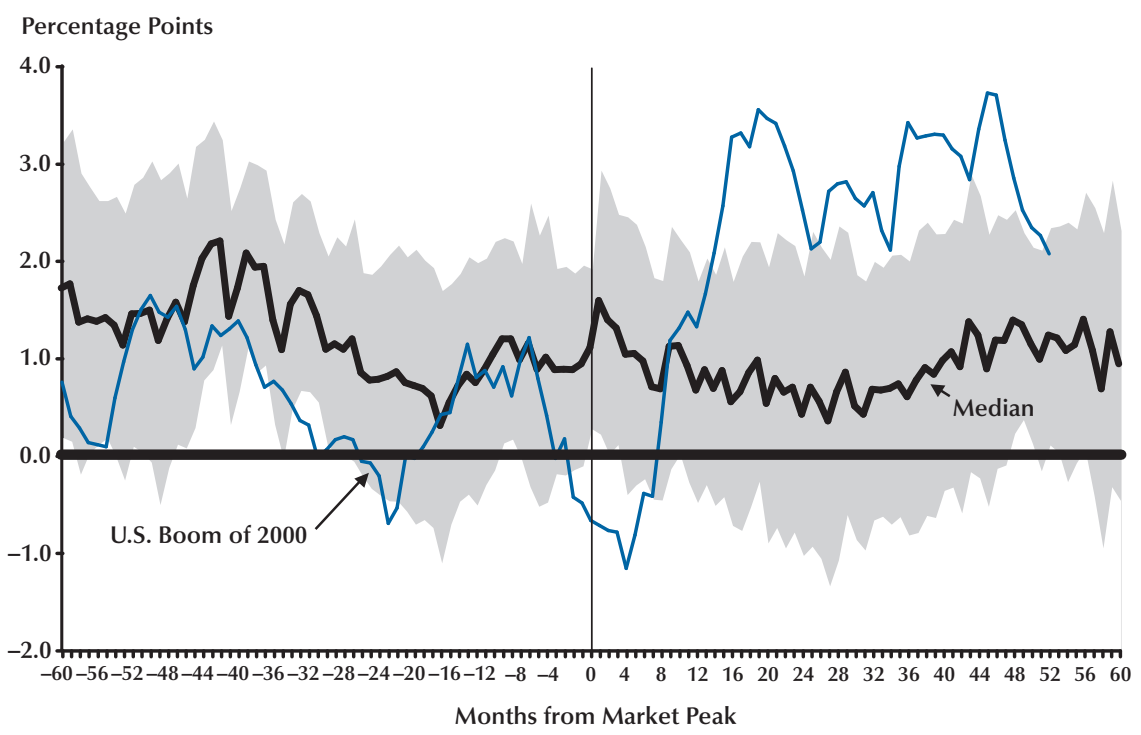

NOTE: The shaded area comprises the median \pm the mean absolute deviation. 
monetary policy tightened. Concern about stock market speculation and rapid economic growth kept the Fed from cutting its funds rate target, even as inflation fell, which effectively allowed policy to tighten.

The next major move in monetary policy came in response to a sudden demand for liquidity in the wake of a Russian government bond default and spreading financial crisis in Asia during the summer and fall of 1998. The Fed cut its funds rate target by 75 basis points between September and November 1998 (months "-23” and “-21”), and the real interest rate fell. The spread between long-term Treasury security yields and short-term interest rates also rose as the demand for liquidity abated.

Inflation began to rise in 1999; citing "a significant risk of rising inflation," the FOMC began to raise its federal funds rate target in June (Board of Governors of the Federal Reserve System, 1999, p. 242). Over the subsequent year, the Committee increased its target by a total of 175 basis points. ${ }^{19}$ For the most part, however, increases in the federal funds rate merely kept pace with the rising inflation rate, which left the real interest rate essentially unchanged. Fed officials sought to contain inflation throughout the period, but resisted the temptation to increase the funds rate faster than the inflation rate because they desired to accommodate a perceived increase in the potential growth rate of the economy associated with higher productivity growth. Fed officials also worried that aggressive tightening could cause a sharp decline in the stock market and a substantial slowing of economic activity. ${ }^{20}$

By mid-2000, Fed officials had decided to act more aggressively against inflation. At their May 2000 meeting, FOMC members concluded that demand growth was continuing to exceed even the increased rate of potential output growth and that more aggressive tightening was necessary: "A more forceful policy move...was desirable in light of the extraordinary and persisting strength

\footnotetext{
${ }^{19}$ The target had been reduced from 5 percent to 4.75 percent on November 17, 1998. The target was raised to 5 percent on June 30 , 1999, and elevated in five more steps to 6.5 percent as of May 16, 2000.

${ }^{20}$ Meyer (2004, pp. 162-63).
}

of overall demand, exceeding even the increasingly rapid growth of potential supply" (Board of Governors of the Federal Reserve System, 2000, p. 224). Thus, rather than increasing their funds rate target by the usual 25-basis-point increment, Fed officials voted to raise their target by 50 basis points to 6.5 percent, where it remained throughout the rest of 2000. As shown in Figures 5 and 6, the real interest rate rose and the term spread declined sharply during the six months preceding the August 2000 peak in real stock prices. Hence, by conventional measures, the stock market boom ended after several months of increasingly tighter monetary policy. ${ }^{21}$

Figures 5 and 6 also plot the median real interest rate and term spread levels across all post1970 booms in our dataset. The pattern followed by the median real rate level is similar to that of the real federal funds rate during the U.S. boom of 1994-2000: After peaking near 4 percent some 24 months before a stock market peak, the median real rate fell approximately 1 percentage point before rising again during the year preceding the market peak. The median term spread does not, however, exhibit the decline observed in the U.S. term spread during the last months of the U.S. boom of 1994-2000. Nevertheless, it appears that, like the U.S. stock market boom of 1994-2000, the end of the "typical" post-1970 boom followed some tightening of monetary policy associated with rising inflation.

\section{MONETARY POLICY AND STOCK MARKET BOOMS BEFORE 1970}

Next we examine the economic and monetary policy conditions under which stock market booms occurred earlier in the 20th century. The historical approach enables us to examine the association of booms with macroeconomic con-

\footnotetext{
21 The specific ending date of the boom is ambiguous. Although we date the end of the boom as the month that the inflation-adjusted S\&P 500 composite index reached its peak (based on monthly averages of daily closing values), the peak in the nonadjusted index occurred on March 24. The dates on which other indices peaked include the Dow Jones industrial average on January 14, the New York Stock Exchange composite index on September 1, and the NASDAQ composite index on March 10.
} 


\section{Figure 7}

\section{Real GDP Growth Relative to Its Long-Run Average: Prewar Booms}

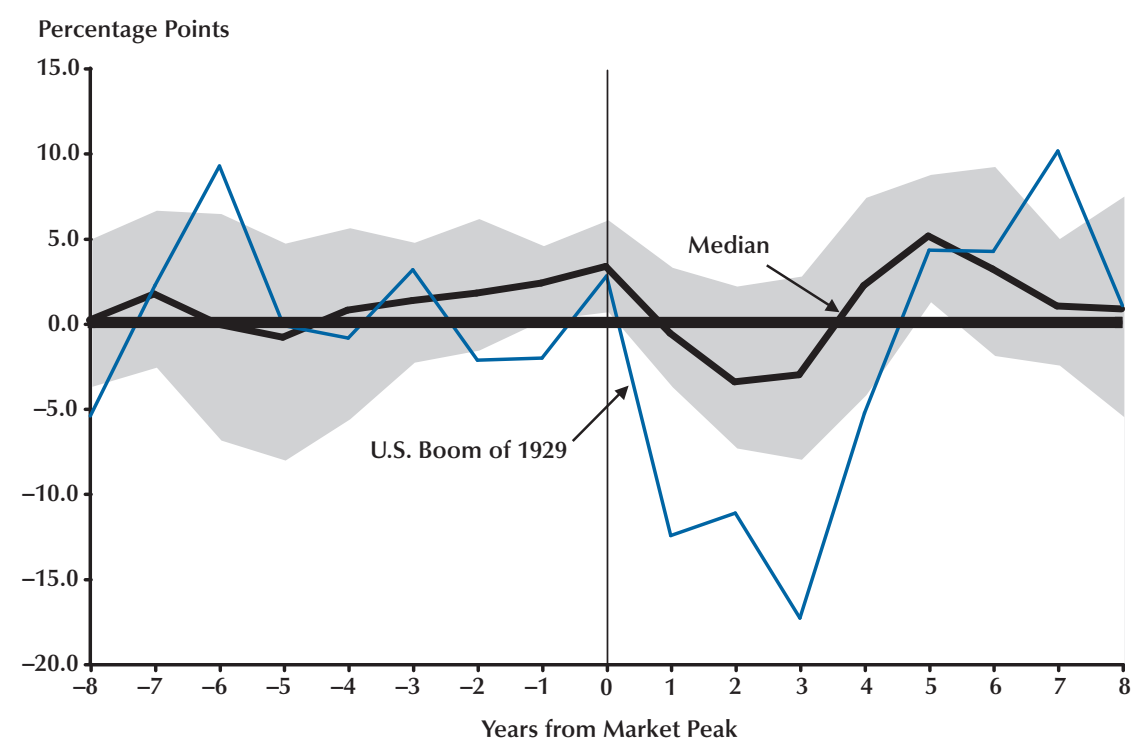

NOTE: The shaded area comprises the median \pm the mean absolute deviation.

ditions and monetary policy under different monetary and financial regulatory regimes.

\section{Pre-World War II Booms}

The stock market booms of 1923-29 and 19942000 stand out among all U.S. booms in terms of their length and the extent to which stock prices rose, and they have often been compared to one another. Like the 1990s boom, the U.S. boom of 1923-29 arose during a period of above average economic growth and low inflation. As with the recent boom, in the 1920s, many analysts attributed the booming stock market to advances in technology and business management techniques that promised rapid growth of economic activity and corporate profits. ${ }^{22}$ Technological breakthroughs of the late-19th and early-20th centuries, especially in electric power distribution and motors, were widely adopted by American industry in the 1920s (David, 1990). Productivity growth

${ }^{22}$ See Bordo and Wheelock (2006) and White (2006) and the references therein. increased sharply, especially in the manufacturing sector. For the private domestic economy as a whole, total factor productivity and labor productivity grew at average annual rates of 2.0 percent and 2.2 percent, respectively, during 1919-29, compared with rates of 1.1 percent and 1.5 percent during 1909-19 and 1.6 and 1.8 percent during 1929-37 (Kendrick, 1961, p. 72). ${ }^{23}$

Figure 7 plots U.S. real GDP growth relative to its long-run average during 1929 (year "0") and the 16 surrounding years. ${ }^{24}$ The figure also plots median real GDP growth (relative to its long-run average) across all prewar booms in our dataset, including the U.S. boom of 1923-29. U.S. output growth was especially rapid at the start of the

${ }^{23}$ Annual data suggest, however, that productivity growth was slower toward the end of the 1920s when the stock market boom was in full swing than it had been earlier in the decade. Total factor productivity growth and labor productivity growth averaged 2.6 and 3.0 percent during 1920-24 and 1.3 and 1.7 percent during 1925-29 (Kendrick, 1961, Table A-XXII). Productivity change is, however, more correctly measured between similar points in the business cycle.

${ }^{24}$ We define the long-run average real GDP growth rate as the average annual rate for 1871-1939. 
Figure 8

Inflation Rate Relative to Its Long-Run Average: Prewar Booms

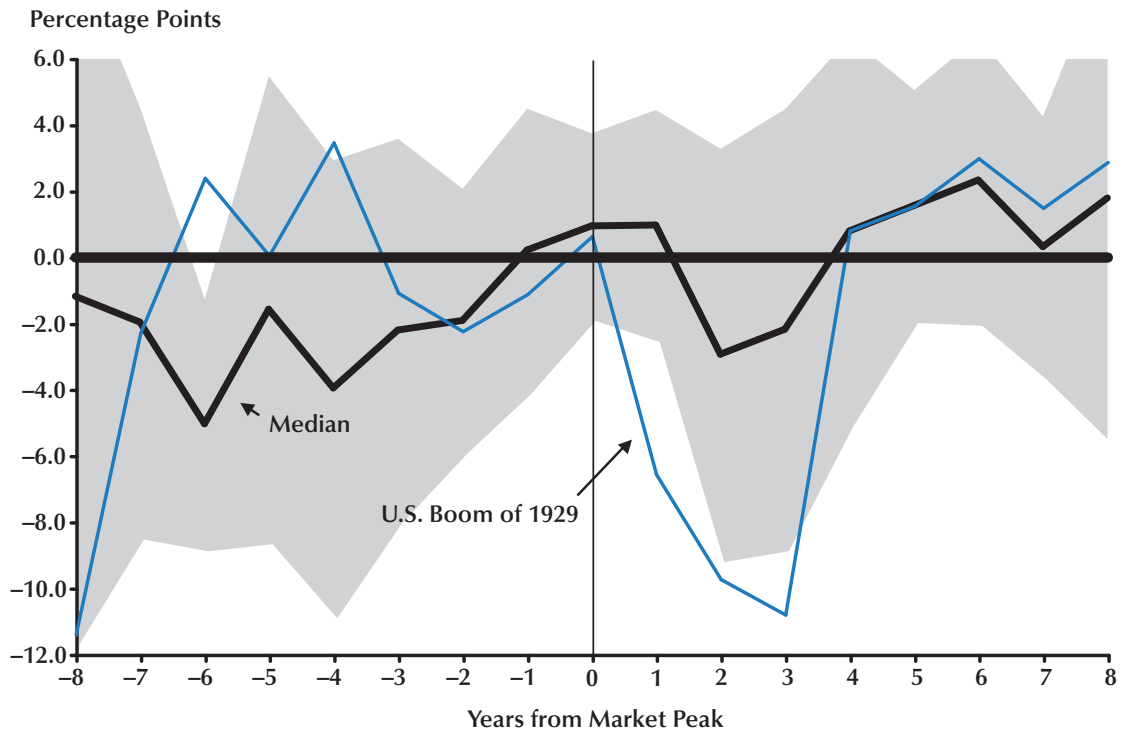

NOTE: The shaded area comprises the median \pm the mean absolute deviation.

\section{Figure 9}

\section{Commercial Paper Rate: 1920s Booms}

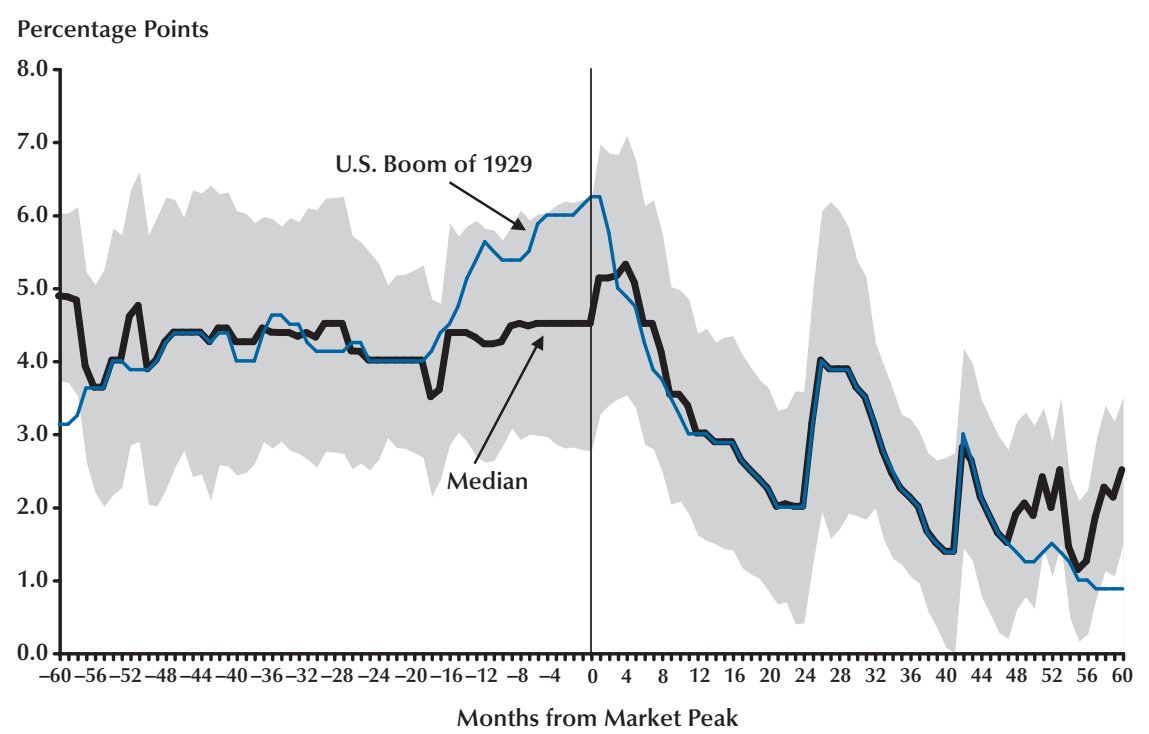

NOTE: The shaded area comprises the median \pm the mean absolute deviation. 
boom in 1923 (year "-6”) and also in 1929 (year "0"), when output growth exceeded its long-run average by 2.8 percentage points. Output growth was below its long-run average, however, in 1927 and 1928. ${ }^{25}$ By contrast, median output growth across all booms exceeded its long-run average during both market peak years and the three years preceding the peak.

Figure 8 shows the behavior of inflation during the U.S. boom of 1923-29, as well as the median inflation rate across all prewar booms in our dataset. U.S. inflation was below average during 1926-28 and approximately equal to its longrun average during 1929. The modest increase in the inflation rate during the last year of the boom is similar to the pattern observed during the U.S. boom of 1994-2000 and in the median across all post-1970 booms. Figure 8 also shows an increase in the median rate of inflation toward the end of prewar booms in general. Thus, like the typical post-1970 stock market boom, the typical prewar boom arose when inflation was below average and ended within a year or two of higher inflation.

The Federal Reserve System was established in 1914, and monetary policy was still in its infancy during the 1920s. World War I disrupted the international gold standard, but the United States only briefly suspended gold payments during the war. The Federal Reserve Act required the System to maintain a gold reserve, but by the early 1920s, the Fed's gold reserves were sufficient to allow policymakers to pursue discretionary monetary policy. Fed officials successfully resisted attempts by Congress to impose an explicit inflation objective on the Fed, and Fed officials made few public statements about their policy objectives or tactics. The Fed pursued a strategy aimed at manipulating bank reserves and market interest rates to achieve an evolving set of objectives, which by 1928 included control of the booming stock market. ${ }^{26}$

\footnotetext{
${ }^{25}$ Throughout this article we use annual real GDP data from Maddison (2003), which are adjusted to be comparable across countries. Quarterly estimates of U.S. real gross national product from Balke and Gordon (1986) indicate that output growth exceeded its long-run (i.e., 1875-1939) average by 0.9 percentage points during 1923:Q11929:Q3 and by 3.5 percentage points during 1928:Q1-1929:Q3.

${ }^{26}$ See Chandler (1958), Friedman and Schwartz (1963), Meltzer (2003), Wheelock (1991), and Wicker (1966) for discussion and evidence on the Fed's policy objectives and strategy during the 1920s.
}

The Federal Reserve tightened monetary policy aggressively in 1928-29, prompted by the rapid rise in stock prices and a perception that Federal Reserve credit was being used to finance speculative activity. Fed officials viewed speculation in stocks, commodities, and other assets as a manifestation of inflation that called for a tightening of credit conditions.

Figure 9 plots the interest rate on commercial paper of four- to six-month maturity during the stock market boom of 1923-29, as well as the median level of short-term interest rates across all booms of the 1920s in our data set. ${ }^{27}$ The figure shows a sharp increase in U.S. short-term interest rates during the 18 months ending in September 1929, coinciding with the Fed's tightening. The median interest rate level across all booms rose much less.

Figure 10 plots the real commercial paper interest rate during the stock market boom of 1923-29 and the median level of interest rates across all booms of the decade. The U.S. real rate increased from an average of 4.7 percent during 1926-27 to an average of 6.0 percent between January 1928 and September 1929. The median across all 1920s booms followed a somewhat different pattern, first declining some 18 months before the stock market peak, then rising in the six months before the market peak. ${ }^{28}$

The Fed's monetary policy tightening of 192829 is also evident in the behavior of the money stock. Figure 11 plots the growth rate of the money stock relative to its long-run average during the U.S. boom of 1923-29 and the median growth rate across all prewar booms. ${ }^{29}$ U.S. money stock growth fell below its long-run average in 1926 and trended downward to a low point in 1932.

\footnotetext{
${ }^{27}$ We lack commercial paper rate data for Australia and Canada for the prewar period.

${ }^{28}$ We do not include a figure with the term spread because market yield data on both a short- and long-term government security are not available for many countries during the 1920s. U.S. short-term interest rates rose relative to long-term rates over the 18 months ending in September 1929, with the commercial paper rate rising from about 100 basis points above the long-term U.S. Treasury bond yield to about 250 basis points above the Treasury yield. Hence, the yield curve became increasingly inverted.

${ }^{29}$ Here we define the long-run average money stock growth rate as the average rate during 1881-1939.
} 


\section{Figure 10}

\section{Real Commercial Paper Rate: 1920s Booms}

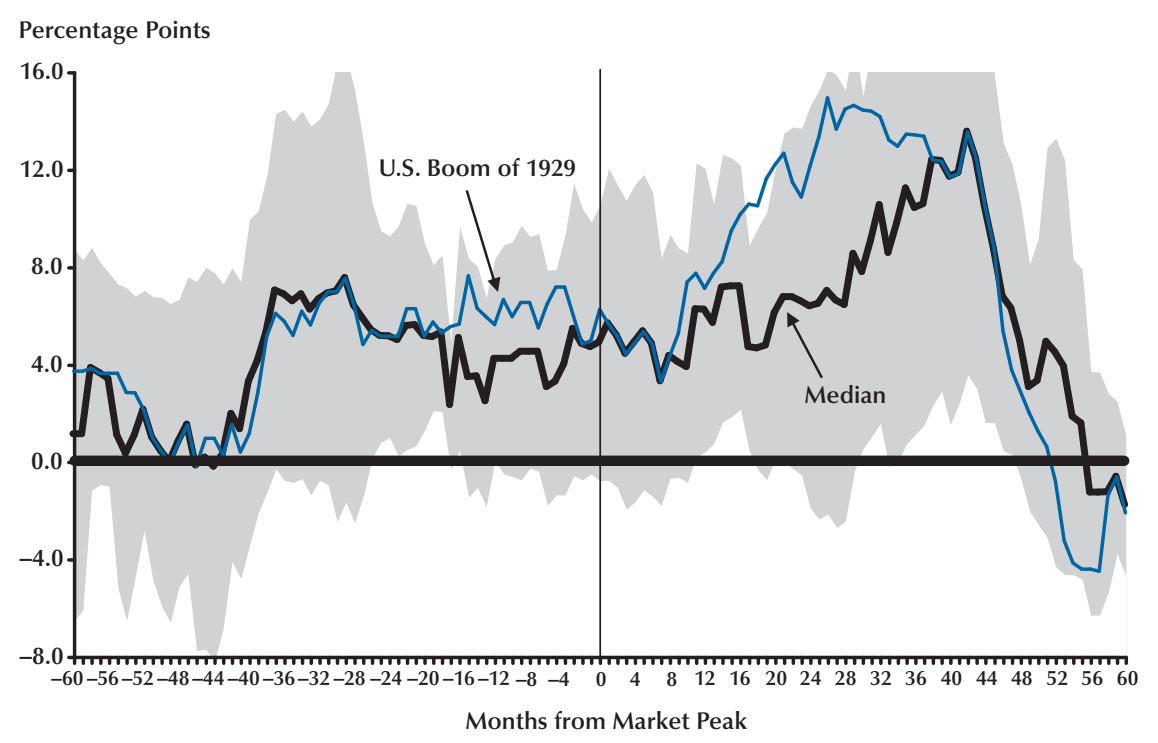

NOTE: The shaded area comprises the median \pm the mean absolute deviation.

Figure 12 shows that the growth of the real money stock also declined relative to its long-run average, especially in 1929. By contrast, median nominal and real money stock growth rose during the year of market peaks, as Figures 11 and 12 also show. Thus, the Fed's policy tightening over the 18 months before the stock market peak in September 1929 was considerably more aggressive than the tightening that occurred toward the end of the typical prewar boom.

Although the Federal Reserve provided substantial liquidity following the October 1929 stock market crash, monetary conditions tightened again in 1930 and the U.S. economy plunged into a depression. Real interest rates soared (see Figure 10), and both the nominal and real money stocks collapsed (see Figures 11 and 12). Real GDP and the price level both fell sharply (see Figures 7 and 8). Although concerned about the economy, the Federal Reserve failed to mount an aggressive response to the Depression, in part because policymakers were fearful of reigniting stock market speculation. ${ }^{30}$ In the event, the real value of the Standard and Poor's composite stock price index fell some 80 percent from its 1929 peak to its low in 1932.

Many countries experienced significant declines in economic activity and stock prices during the Great Depression. Several, including the United States, also experienced a stock market boom as their economies recovered. In many countries, recovery began when their currency was devalued or the country abandoned the gold standard (Eichengreen, 1992). Stock markets recovered and boom periods were characterized by rapid output and money stock growth and moderate inflation.

U.S. stock prices rose rapidly during the mid1930s: The Standard and Poor's composite index rose at an inflation-adjusted rate of nearly 40 percent per year between March 1935 and February 1937. The boom ended abruptly in early 1937, however, and the U.S. economy entered a recession. Once again, the end of the boom coincided with a tightening of monetary conditions.

\footnotetext{
${ }^{30}$ See Friedman and Schwartz (1963), Meltzer (2003), and Wheelock (1991 and 1992) and the references therein for explanations of the Fed's behavior during the Great Depression.
} 


\section{Figure 11}

\section{Money Stock Growth Relative to Its Long-Run Average: Prewar Booms}

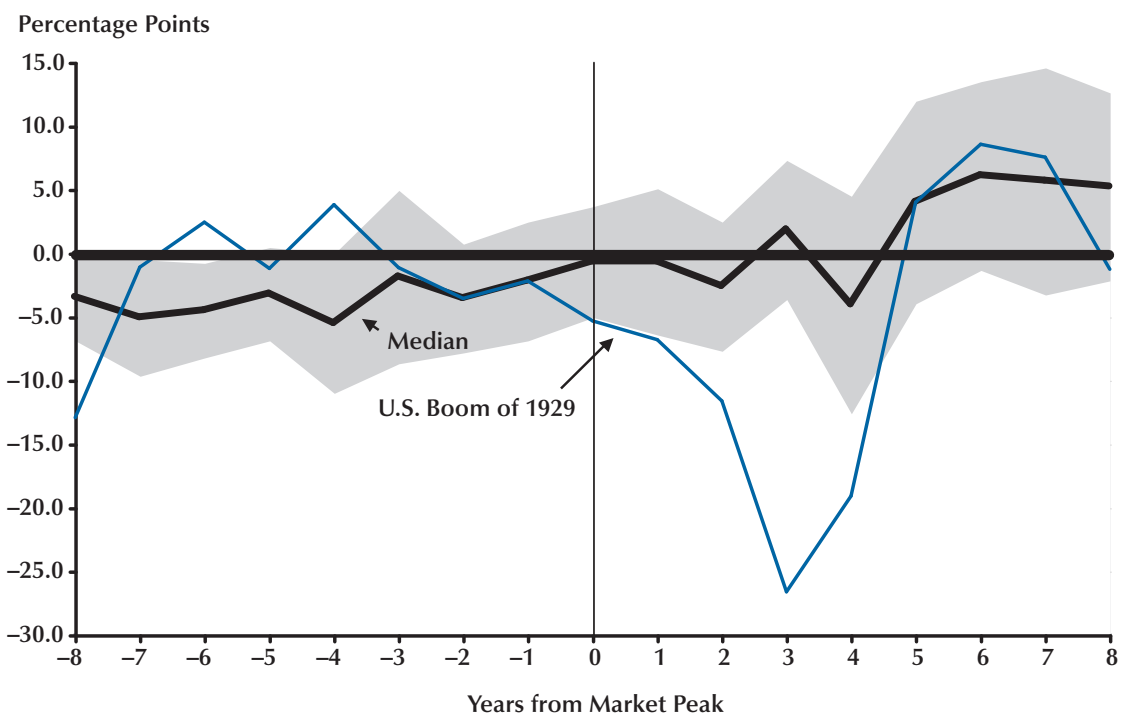

NOTE: The shaded area comprises the median \pm the mean absolute deviation.

\section{Figure 12}

\section{Real Money Stock Growth Relative to Its Long-Run Average: Prewar Booms}

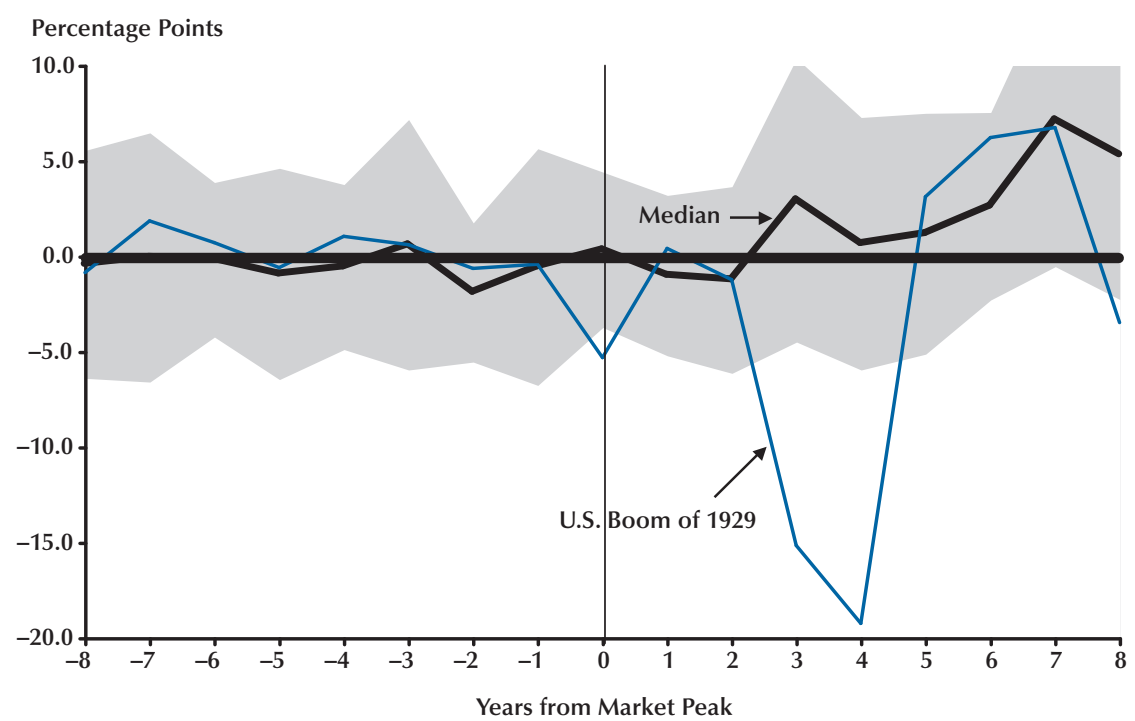

NOTE: The shaded area comprises the median \pm the mean absolute deviation. 
The Federal Reserve had largely stayed on the sidelines as the U.S. economy pulled out of the Depression and the pace of economic activity accelerated. As the recovery continued, however, Fed officials became increasingly concerned about the potential for inflation. Beginning in 1933, gold inflows caused bank reserves and the money stock to grow rapidly, and banks built up huge stocks of reserves in excess of legal requirements. Fed officials feared that the accumulation of excess reserves posed an inflationary threat and took a series of steps to reduce them: The Federal Reserve Board increased reserve requirements by 50 percent in August 1936; the Treasury Department began to neutralize gold inflows in December 1936; and the Fed hiked reserve requirements again on January 30, 1937. Following these actions, money stock growth slowed (from 13 percent in 1936 to 4 percent in 1937), interest rates rose, and the stock market peaked and began to fall as the boom ended.

\section{Early Postwar Booms}

We examine stock market booms of the 1950s and 1960s separately from those of the 1970s to 1990s because of sharp differences in the regulatory and monetary regimes that prevailed in the two periods. In addition, for some countries, highfrequency economic and financial data are not available for the 1950s and 1960s.

Many countries adopted new regulations on financial markets and international capital flows in response to the financial disruptions of the Great Depression. The Great Depression also effectively ended the international gold standard, as countries either abandoned the standard altogether or imposed exchange controls that limited its functioning (Eichengreen, 1992). World War II brought even tighter controls, especially in Europe, that included restrictions on the issuance of private securities and the movement of capital across international borders. The postwar international monetary system was defined by the Bretton Woods system of fixed exchange rates and capital controls. Wartime controls were gradually relaxed over time, but deregulation was protracted. The pace of deregulation quickened in the 1970s and 1980s as countries sought to keep their financial markets competitive in the face of advances in information-processing technology that encouraged financial innovation and globalization. At the same time, the international monetary regime changed dramatically with the collapse of the Bretton Woods system in $1971 .{ }^{31}$

The United States experienced two stock market booms during the 1950s and 1960s, one ending in April 1956 and another ending in January 1966. Figure 13 plots data on U.S. real GDP growth relative to its long-run average during these two episodes. The figure also plots the median growth rates across all booms of the 1950s and 1960s in our data set, as well as the mean absolute deviation of observations around the median.

U.S. output growth was highly variable during the boom of 1953-56. As shown in Figure 13, real GDP contracted by almost 1 percent in 1954 (year “-1"), but expanded by nearly 7 percent in 1955 (year "0"). ${ }^{32}$ Output growth was less variable during the stock market boom of 1962-66 and exceeded its long-run average throughout the period. Output growth exceeded its long-run average by nearly 3 percentage points in 1965 (year "0") and continued to grow rapidly after the peak in the real stock price index in January 1966. Median real GDP growth exceeded its long-run average across all booms of the 1950s and 1960s, and rose during the final two years of booms. Output growth was unusually rapid during the 1950s and 1960s, especially among European countries and Japan. Whereas U.S. output growth fell below its long-run average within a year of the U.S. stock market peaks in April 1956 and January 1966, median output growth remained above its longrun average after the "typical” stock market boom of the 1950s and 1960s had ended. ${ }^{33}$

\footnotetext{
${ }^{31}$ See Bordo and Wheelock (2006) for additional discussion and evidence on changes over time in the coincidence of stock market booms and correlation of stock returns across our sample countries. See also Goetzmann, Li, and Rouwenhorst (2001) and Obstfeld and Taylor (1998) for evidence on the international integration of financial markets throughout the 20th century.

${ }^{32}$ As noted previously, in figures that present annual data, we define year " 0 " as the year prior to the actual market peak if the peak occurred during the first half of a calendar year.

${ }^{33}$ On the "Golden Age" of European economic growth before 1973, see Crafts and Toniolo (1996).
} 


\section{Figure 13}

\section{Real GDP Growth Relative to Its Long-Run Average: 1950s-60s Booms}

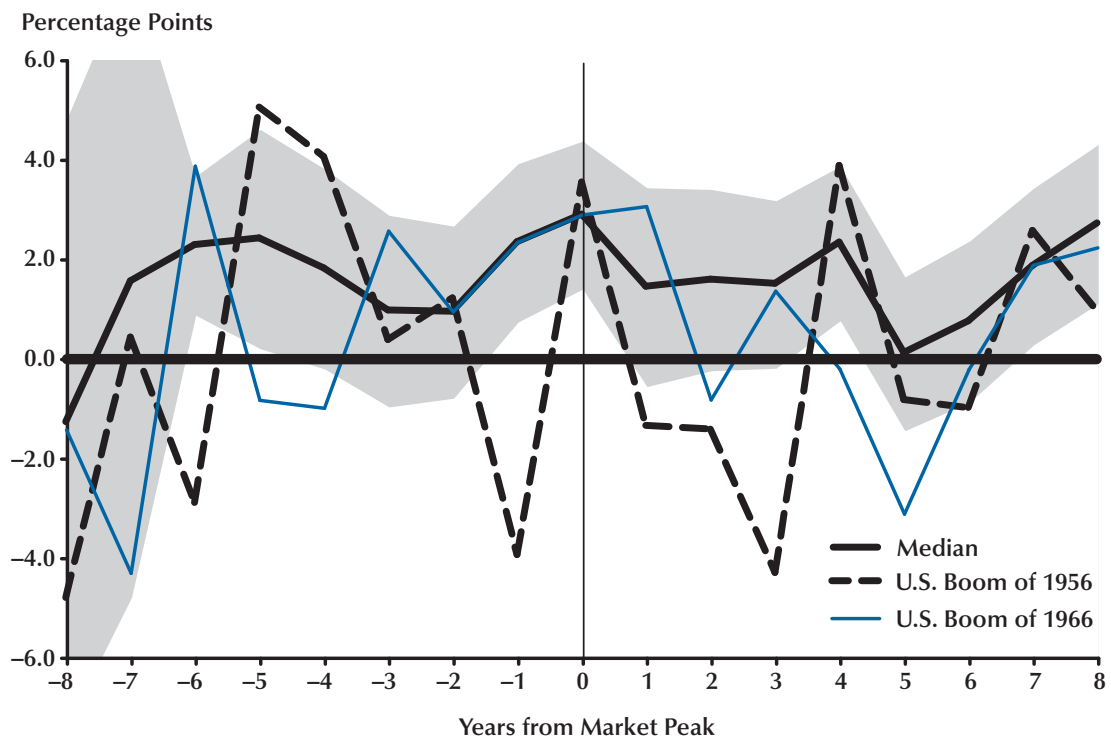

NOTE: The shaded area comprises the median \pm the mean absolute deviation.

\section{Figure 14}

\section{Inflation Rate Relative to Its Long-Run Average: 1950s-60s Booms}

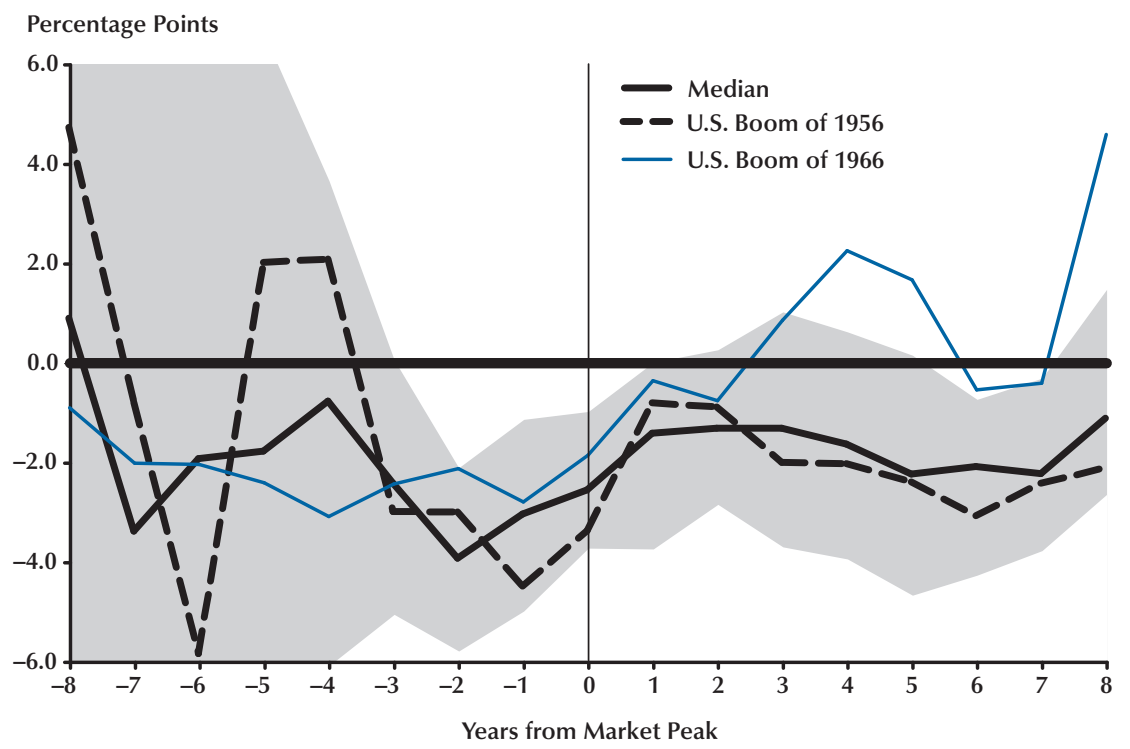

NOTE: The shaded area comprises the median \pm the mean absolute deviation. 


\section{Figure 15}

\section{Short-Term Interest Rate Relative to Its Rate in Peak Month: 1950s-60s Booms}

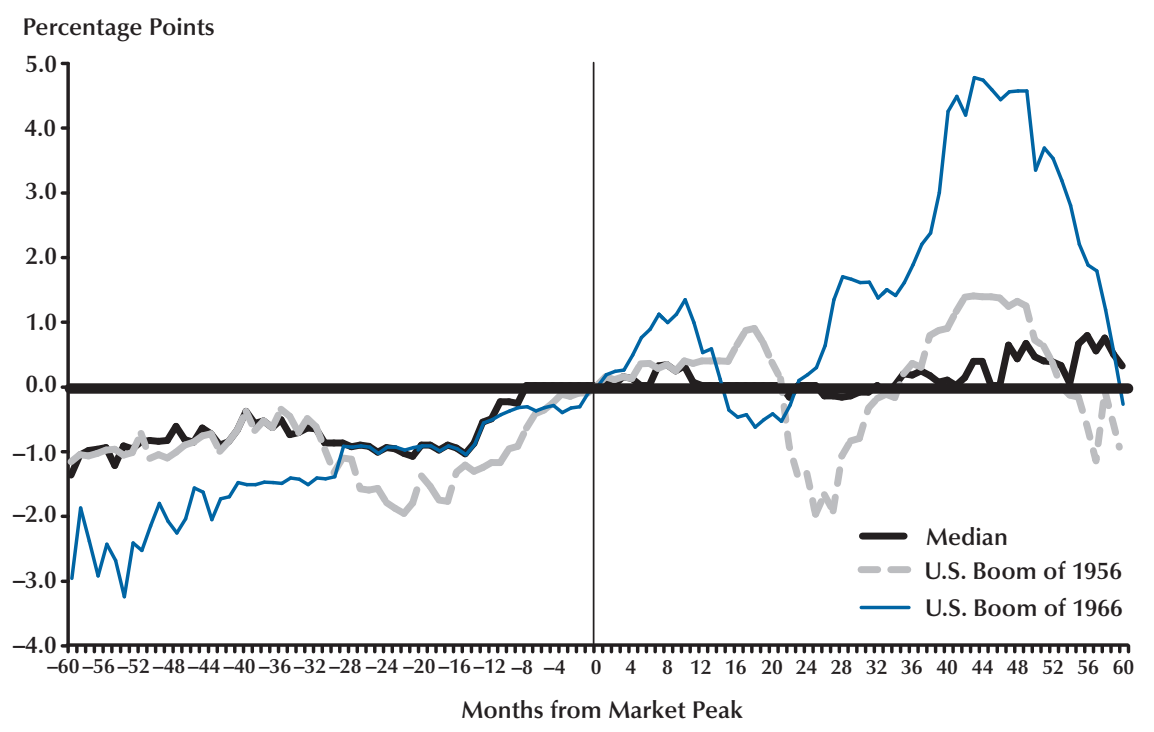

Figure 14 plots inflation rates (relative to their long-run averages) during the two U.S. stock market booms of the 1950s and 1960s, alongside median inflation across all booms of the period and the mean absolute deviation of observations around the median. As during both the prewar and post-1970 periods, during the 1950s and 1960s stock market booms typically arose when inflation was below its long-run average and ended after inflation had risen. The U.S. booms of the 1950s and 1960s were no exception. After a burst of inflation during the Korean War, the U.S. inflation rate stayed below 1 percent per year throughout 1952-55, before rising to 3 percent in 1956-57. Inflation then fell back and remained below 2 percent in each year from 1958 to 1965. Inflation rose again in 1965, however, and reached 3.4 percent in 1966.

Resembling the patterns of both prewar and post-1970 booms, the increases in inflation before the U.S. stock market peaks in 1956 and 1966 were accompanied by higher interest rates and other evidence of monetary tightening. Figure 15 plots data on short-term interest rates during the two U.S. booms and the median across all booms of the 1950s and 1960s. ${ }^{34}$ The figures show the level of the interest rate in each month relative to its level in the month when the real stock price index reached its peak (month " 0 ").

Short-term interest rates rose some 2 percentage points over the 24 months ending in April 1956, reflecting actions by the Federal Reserve to ward off inflation and curb the flow of credit to the stock market. The Fed began a series of tightening steps in 1954 that included open-market operations and hikes in the discount rate and margin requirements. ${ }^{35}$ Fed officials continued to focus on inflation during 1955 and 1956 and frequently discussed the importance of preventing inflation from rising. For example, at an FOMC

\footnotetext{
${ }^{34}$ When available, we use an overnight interest rate, such as the U.S. federal funds rate, in constructing the interest rate series for this period. Otherwise, we use a short-term Treasury security yield. Monthly data on the federal funds rate are not available until July 1954 , for example, and so we use the yield on 3-month Treasury bills for earlier months.

35 The Securities Exchange Act of 1934 empowered the Federal Reserve Board to regulate margin requirements on loans granted by banks and securities firms for the purpose of purchasing or owning stocks. The margin requirement establishes the minimum percentage of a stock purchase that must be self-financed rather than financed by borrowing.
} 


\section{Figure 16}

\section{Real Short-Term Interest Rate: 1950s-60s Booms}

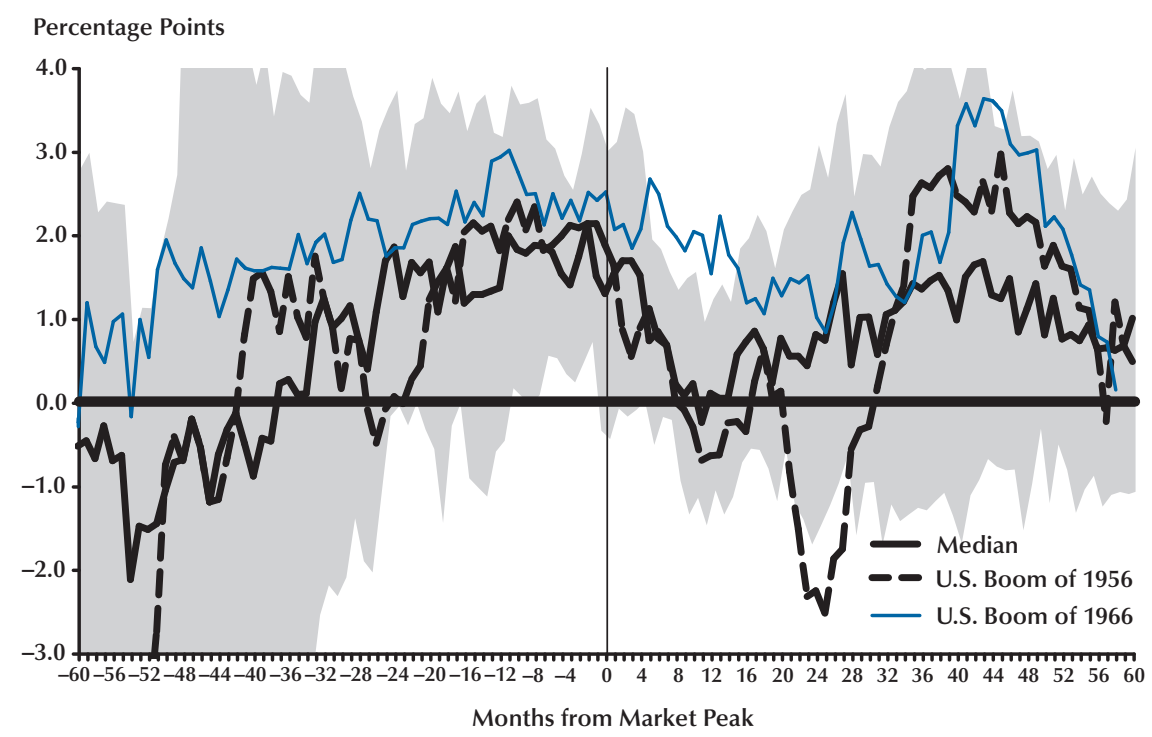

NOTE: The shaded area comprises the median \pm the mean absolute deviation.

meeting in January 1955, Chairman William McChesney Martin Jr. stated that "[w]hat we are wrestling with at the moment is the possibility that inflationary seeds may be germinating, and that when they come to full bloom it will be difficult to restrain them...We want to nip inflation in the bud" (Federal Open Market Committee, January 11, 1955, pp. 7-8). Martin also expressed concern about the booming stock market, arguing that "we ought to be considering the possibility of another signal to the stock market either through a further increase in the margin or, preferably through the discount rate" (p. 9).

Fed officials expressed concern about the booming stock market throughout 1955, occasionally associating movements in stock prices with general price inflation. For example, at an FOMC meeting in August, Chairman Martin commented that "all danger signals are now flashing red. Inflation is a thief in the night and if we don't act promptly and decisively we will always be behind...A move such as we had in General Motors (stock) of fifteen points in one day would be disastrous if it developed over the whole price level” (Federal Open Market Committee, August 2, 1955, p. 13).

In the event, inflation remained low throughout 1954 and 1955 and, consequently, the increase in short-term interest rates during these years resulted in a similar-sized increase in the real interest rate, as shown in Figure 16. Money stock growth also slowed, as shown in Figure 17, though real money stock growth remained slightly above its long-run average, as shown in Figure $18{ }^{36}$

Monetary conditions did not tighten as sharply before the U.S. stock market peak in January 1966 as they had before the April 1956 peak. As shown in Figure 15, the federal funds rate rose by approximately 0.5 percentage points

${ }^{36}$ Calomiris and Wheelock (1998) note a close, negative correlation between the level of free reserves and inflation during the 1950s. Further, they note that growth of the money stock (M1) was positively correlated with the level of free reserves during the 1950s, but not during the 1960s, which could explain the Fed's apparent success in maintaining low inflation during the 1950s, but not during the 1960s. Romer and Romer (2002) find that Fed policy was consistent with the "Taylor principle" during the 1950s, but not during the 1960s, in that movements in the real interest rate were sufficient to stabilize inflation during the 1950s, but not during the 1960s. 
Figure 17

Money Stock Growth Relative to Its Long-Run Average: 1950s-60s Booms

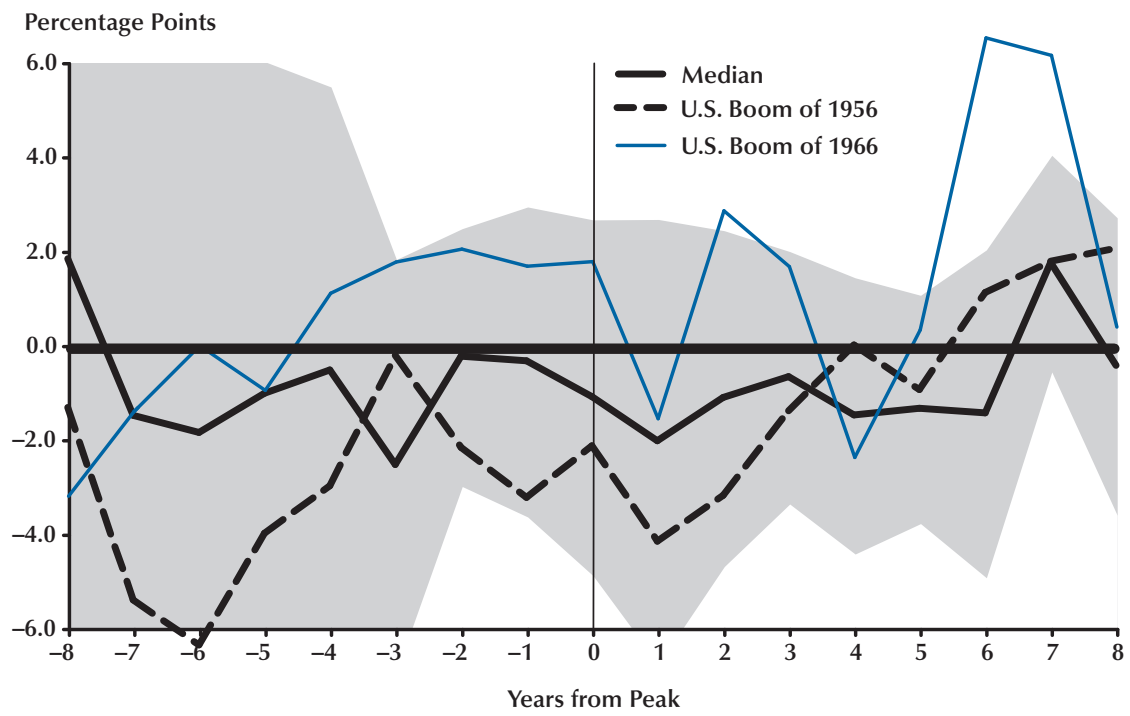

NOTE: The shaded area comprises the median \pm the mean absolute deviation.

\section{Figure 18}

Real Money Stock Growth Relative to Its Long-Run Average: 1950s-60s Booms

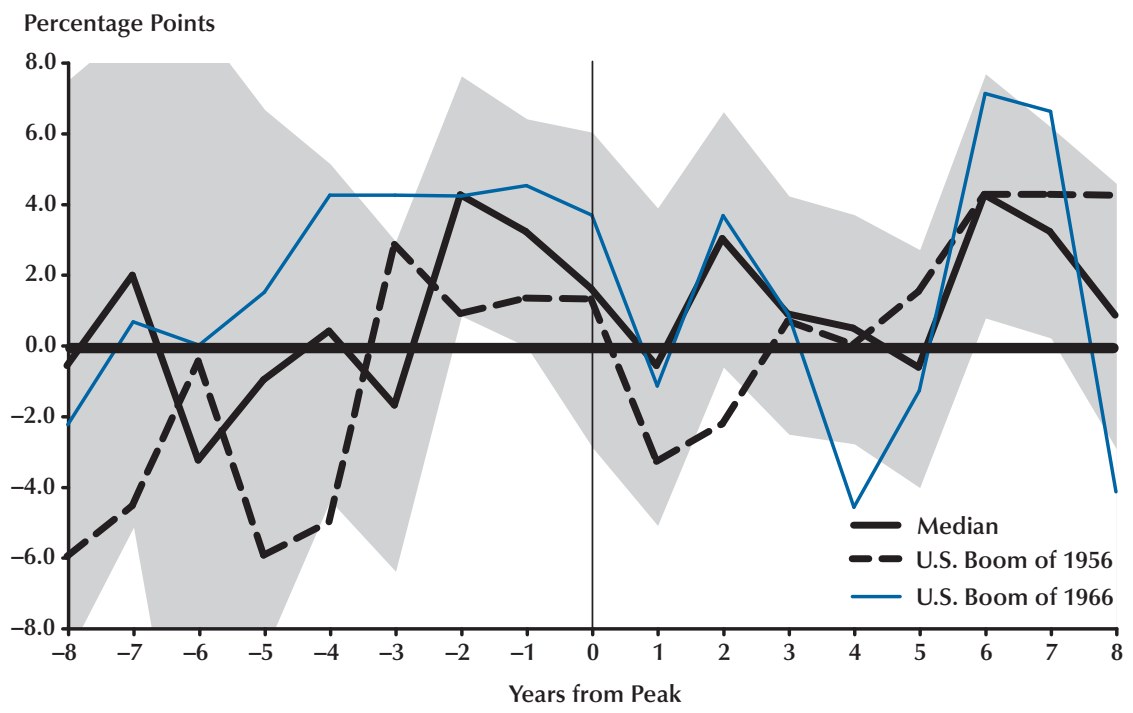


in late 1964 (months “-15” to “-13”), but changed little during 1965. The real funds rate, shown in Figure 16, peaked in early 1965 (month “-11”), then declined in the second quarter when inflation began to rise. The real funds rate then changed little over the remainder of the year. Further, both nominal and real money stock growth remained above their long-run average rates during 1965 (year " 0 " in Figures 17 and 18).

The January 1966 stock market peak did, however, occur shortly after a highly publicized monetary policy action. The increase in inflation in the second quarter of 1965 persisted through the remainder of the year, and by the fourth quarter Fed officials were convinced that monetary policy had to tighten. Memoranda from the FOMC meeting in November state that Chairman Martin argued that "the country was in a period of creeping inflation...In short, he thought the economy was growing too fast at the moment" (FOMC, November 23, 1965, p. 85). Fed officials then took steps to tighten, including a highly publicized discount rate increase in early December that sparked a sharp rebuke from President Johnson. ${ }^{37}$ The stock market peak occurred shortly thereafter, and the boom of 1962-66 was over.

Other countries that had booms during the 1950s and 1960s experienced interest rate and money stock growth patterns that were similar to those of the two U.S. booms. The median level of short-term interest rates across all booms rose by 1 percentage point during the 8 to 15 months before stock market peaks. The median real interest rate level fluctuated widely, with little trend during the 24 months before market peaks; but both nominal and real money stock growth declined during the last two years of booms, indicating that some monetary policy tightening preceded the end of the typical boom.

\section{OBSERVATIONS AND CONCLUSIONS}

The U.S. stock market boom of 1994-2000 arose during a period of unusually rapid growth

\footnotetext{
${ }^{37}$ See Maisel (1973, pp. 69-77).
}

of output and productivity and low inflation. Technological advances and higher productivity growth convinced many observers that corporate profits would continue to grow rapidly and justify soaring equity prices. Further, shrinking government budget deficits and low inflation suggested that interest rates would remain low. Eventually, however, inflation began to rise, monetary policy tightened, and the boom ended.

Our review of earlier stock market booms in the United States and nine other developed countries during the 20th century indicates that the patterns observed during the U.S. boom of 1994-2000 were similar to those of earlier booms. Stock market booms typically arose when output growth exceeded its long-run average and when inflation was below its long-run average. There were, however, exceptions. Notably, we find that across all post-1970 booms the median growth rates of real GDP and productivity did not substantially exceed their long-run averages. ${ }^{38} \mathrm{We}$ find less variation in the association of booms with low inflation than we do in the association of booms with rapid output or productivity growth. Further, we find that both nominal and real money stock growth were typically below average during booms, suggesting that booms did not result from excessive liquidity. ${ }^{39}$

We find that 20th century stock market booms often ended following an increase in inflation and a tightening of monetary conditions. All U.S. booms ended after explicit tightening by the Federal Reserve in response to actual or threatened inflation. The Fed tightened policy in 192829 because policymakers believed that asset price appreciation was a form of inflation that required an aggressive response. During subsequent booms,

\footnotetext{
${ }^{38}$ Bordo and Wheelock (2006) speculate that increased financial globalization since the 1970s may have weakened the connection between stock market performance and domestic output growth in some countries. Further, among European countries, stock market performance in the 1990s may have been heavily influenced by steps taken to integrate national economies, especially monetary union.

${ }^{39}$ Some analysts have argued that asset booms reflect excessive growth of credit. We have been unable to locate data on credit that are comparable across all of the countries in our sample, especially for earlier periods. A cursory review of what data we have obtained, however, shows no consistent association of booms with credit growth.
} 


\section{Bordo and Wheelock}

the Fed's principal goal was to halt an incipient rise in consumer price inflation, though concern about stock market speculation appears to have been a secondary reason for tightening in some cases.

Although the U.S. monetary policy regime changed substantially over time, we find little variation in the association of stock market booms with inflation or in the end of booms with monetary policy actions to control inflation. Even under the gold standard of the 1920s, however, the Fed had considerable latitude in pursuing discretionary monetary policy and conceivably the absence of a clear statement of objectives contributed to instability in asset markets. Recent research suggests that the form of rule used by monetary authorities, including its communication strategies, can influence how policy actions affect economic activity. ${ }^{40}$ Additional research is needed, however, to determine whether a clear statement of objectives and strategy to achieve those objectives would alter the association of asset booms with low inflation or the effect that policy actions to control inflation have on asset markets.

\section{REFERENCES}

Balke, Nathan and Gordon, Robert J. "Appendix: Historical Data," in Robert J. Gordon, ed., The American Business Cycle: Continuity and Change. Chicago: University of Chicago Press, 1986, pp. 781-850.

Bernanke, Ben S. and Kuttner, Kenneth N. "What Explains the Stock Market's Reaction to Federal Reserve Policy?" Journal of Finance, June 2005, 60(3), pp. 1221-57.

Board of Governors of the Federal Reserve System. "Minutes of the Federal Open Market Committee, May 16, 2000.” 87th Annual Report, 2000.

Board of Governors of the Federal Reserve System. "Minutes of the Federal Open Market Committee, June 29-30, 1999." 86th Annual Report. 1999.

${ }^{40}$ Bordo et al. (2005), for example, examine three major U.S. disinflations since the Civil War and conclude that both policy institutions and central bank communication strategies affect expectations of disinflation and subsequent economic activity.
Bordo, Michael; Eichengreen, Barry; Klingebiel, Daniela and Martinez-Peria, Maria Soledad. "Is the Crisis Problem Growing More Severe?” Economic Policy, April 2001, 16(32), pp. 51-82.

Bordo, Michael; Erceg, Christopher; Levin, Andrew and Michaels, Ryan. "Three Great American Disinflations." Unpublished manuscript, August 2005.

Bordo, Michael and Wheelock, David C. "Monetary Policy and Asset Prices: A Look Back at Past U.S. Stock Market Booms." Federal Reserve Bank of St. Louis Review, November/December 2004, 86(6), pp. 19-44.

Bordo, Michael and Wheelock, David C. "When Do Stock Market Booms Occur? The Macroeconomic and Policy Environments of 20th Century Booms." Working Paper No. 2006-051A, Federal Reserve Bank of St. Louis, September 2006.

Borio, Claudio and Lowe, Philip. "Asset Prices, Financial and Monetary Stability: Exploring the Nexus." Working Paper No. 114, Bank for International Settlements, July 2002.

Bryan, Michael F.; Cecchetti, Stephen G. and O'Sullivan, Roisin. "Asset Prices in the Measurement of Inflation.” NBER Working Paper No. 8700, National Bureau of Economic Research, January 2002.

Calomiris, Charles W. and Wheelock, David C. "Was the Great Depression a Watershed for American Monetary Policy?” in Michael D. Bordo, Claudia Goldin, and Eugene N. White, eds., The Defining Moment: The Great Depression and the American Economy in the Twentieth Century. Chicago: University of Chicago Press, 1998, pp. 23-65.

Cecchetti, Stephen G. "What the FOMC Says and Does When the Stock Market Booms," in A. Richards and T. Robinson, eds., Asset Prices and Monetary Policy: Proceedings of the Annual Research Conference of the Reserve Bank of Australia. Sydney, Australia: Reserve Bank of Australia, November 2003, pp. 77-96. 
Chandler, Lester V. Benjamin Strong, Central Banker. Washington, DC: Brookings Institution, 1958.

Crafts, Nicholas, and Toniolo, Gianni. Economic Growth in Europe Since 1945. Cambridge: Cambridge University Press, 1996.

David, Paul A. "The Dynamo and the Computer: An Historical Perspective on the Modern Productivity Paradox." American Economic Review, May 1990, 80(2), pp. 355-61.

Eichengreen, Barry. Golden Fetters: The Gold Standard and the Great Depression, 1919-1939. New York: Oxford University Press, 1992.

Fama, Eugene F. and Schwert, G. William. "Asset Returns and Inflation." Journal of Financial Economics, November 1977, 5(2), pp. 115-46.

Federal Open Market Committee. Minutes of the Federal Open Market Committee. Various meetings.

Friedman, Milton and Schwartz, Anna J. A Monetary History of the United States, 1867-1960. Princeton: Princeton University Press, 1963.

Goetzmann, William N.; Li, Linfeng and Rouwenhorst, K. Geert. "Long-Term Global Market Correlations." NBER Working Paper No. 8612, National Bureau of Economic Research, November 2001.

Goodfriend, Marvin. "Interest Rate Policy Should Not React Directly to Asset Prices," in William C. Hunter, George G. Kaufman, and Michael Pomerleano, eds., Asset Price Bubbles: The Implications for Monetary, Regulatory, and International Policies. Cambridge, MA: MIT Press, 2003, pp. 445-57.

Goodhart, Charles A. and Hofmann, Boris. "Do Asset Prices Help Predict Consumer Price Inflation?” Manchester School, 2000, 68(Suppl.), pp. 122-40.

Greenspan, Alan. "The Challenge of Central Banking in a Democratic Society." Remarks at the Annual Dinner and Francis Boyer Lecture of the American Enterprise Institute for Public Policy Research, Washington, DC, December 5, 1996.
Hayford, Marc D. and Malliaris, A.G. "Monetary Policy and the U.S. Stock Market.” Economic Inquiry, July 2004, 42(3), pp. 387-401.

Helbling, Thomas and Terrones, Marco. "Asset Price Booms and Busts-Stylized Facts from the Last Three Decades of the 20th Century." Working paper, International Monetary Fund, March 2004.

Kendrick, John W. Productivity Trends in the United States. Princeton: Princeton University Press, 1961.

Kohn, Donald L. "Monetary Policy and Asset Prices." Remarks at Monetary Policy: A Journey from Theory to Practice, a European Central Bank Colloquium held in honor of Otmar Issing, Frankfurt, Germany, March 16, 2006.

Maddison, Angus. The World Economy: Historical Statistics. Paris: Organisation for Economic Co-operation and Development, 2003.

Maisel, Sherman J. Managing the Dollar. New York: W.W. Norton, 1973.

Meltzer, Allan H. A History of the Federal Reserve, Volume 1: 1913-1951. Chicago: University of Chicago Press, 2003.

Meyer, Laurence H. A Term at the Fed: An Insider's View. New York: Harper Business, 2004.

Obstfeld, Maurice and Taylor, Alan M. "The Great Depression as a Watershed: International Capital Mobility over the Long Run," in Michael D. Bordo, Claudia Goldin, and Eugene N. White, eds., The Defining Moment: The Great Depression and the American Economy in the Twentieth Century. Chicago: University of Chicago Press, 1998, pp. 353-402.

Pagan, Adrian R. and Sossounov, Kirill A. "A Simple Framework for Analysing Bull and Bear Markets.” Journal of Applied Econometrics, January/February 2003, 18(1), pp. 23-46.

Rigobon, Roberto and Sack, Brian. "Measuring the Reaction of Monetary Policy to the Stock Market." Quarterly Journal of Economics, May 2003, 118(2), pp. 639-69. 


\section{Bordo and Wheelock}

Romer, Christina D. and Romer, David H. "A Rehabilitation of Monetary Policy in the 1950s." American Economic Review, May 2002, 92(2), pp. 121-27.

Schwartz, Anna J. "Why Financial Stability Depends on Price Stability." Economic Affairs, Autumn 1995, 15(4), pp. 21-25.

Wheelock, David C. The Strategy and Consistency of Federal Reserve Monetary Policy, 1923-1933.

Cambridge: Cambridge University Press, 1991.

Wheelock, David C. "Monetary Policy in the Great Depression: What the Fed Did and Why." Federal Reserve Bank of St. Louis Review, March/April 1992, 74(2), pp. 3-28.
White, Eugene N. "Bubbles and Busts: The 1990s in the Mirror of the 1920s." NBER Working Paper No. 12138, National Bureau of Economic Research, March 2006.

Wicker, Elmus R. Federal Reserve Monetary Policy, 1917-1933. New York: Random House, 1966.

Woodford, Michael. Interest and Prices: Foundations of a Theory of Monetary Policy. Princeton: Princeton University Press, 2003. 


\section{APPENDIX}

This appendix provides information about the data and sources used in this article. It describes the stock price index data that are used and then provides information about the data used in each figure in the article.

\section{STOCK PRICE INDEX (nominal, monthly data)}

For all countries except the United States, the stock price data are from Global Financial Data (www.globalfinancialdata.com). The following lists the Global Financial Data series identifier and description for each country:

$\begin{array}{ll}\text { Australia: } & \text { AORDM, Australia ASX All-Ordinaries } \\ \text { Canada: } & \text { GSPTSEM, Canada S\&P/TSX 300 Composite } \\ \text { France: } & \text { SBF250M, France SBF-250 Index } \\ \text { Germany: } & \text { FWBXXM, Germany CDAX Composite Index } \\ \text { Italy: } & \text { BCIIM, Banca Commerciale Italiana Index } \\ \text { Japan: } & \text { N225M, Japan Nikkei 225 Stock Average } \\ \text { Netherlands: } & \text { AAXM, Netherlands All-Share Price Index } \\ \text { Sweden: } & \text { SWAVM, Sweden Affarsvarlden General Index } \\ \text { United Kingdom: } & \text { FTASM, UK FT-Actuaries All-Share Index } \\ \text { United States: } & \text { NBER Macro History Database, series m11025a (1871:01-1920:12); } \\ & \text { Standard \& Poor's 500 Composite Index (1941-43=10), monthly average of } \\ & \text { daily data obtained from Haver Analytics (1921:01-2004:12) }\end{array}$

\section{REAL STOCK PRICE (monthly)}

We use consumer price index data to deflate nominal stock prices to obtain a real stock price. For all countries except the United States, our consumer price index data are from Global Financial Data. The following lists the Global Financial Data consumer price index series identifier for each country. Monthly observations are available beginning from the month listed in parentheses.
Australia:
CPAUSM (1912:01)
Canada:
CPCANM (1914:01)
France:
CPFRAM (1915:01)
Germany:
CPDEUM (1923:12)
Italy:
CPITAM (1920:01)
Japan:
CPJPNM (1922:01)
Netherlands:
CPNLDM (1919:01)
Sweden:
CPSWEM (1916:01)
United Kingdom: CPGBRM (1914:01)
United States: $\quad$ BLS, series ID: CUUR0000SA0, CPI-all urban consumers, U.S. city average, all items, not seasonally adjusted, 1982-84 = 100 (1913:01-2004:12)

\section{NOTES ABOUT THE FIGURES}

We compute all growth rates using log first differencing, unless otherwise noted. For all figures displaying annual data, if the peak month of a boom occurred in the first six months of a year, we 


\section{Bordo and Wheelock}

attribute the peak to the prior calendar year. Otherwise, we attribute the peak to the calendar year that it occurred. For figures displaying monthly or quarterly data, we attribute the peak to the actual month or quarter that it occurred.

\section{Figure 1}

Real GDP: Quarterly data were downloaded from the OECD (Organisation for Economic Co-operation and Development) NEQ database of Haver Analytics. Data are available beginning in the quarter listed in parentheses: Australia (1960:Q1); Canada (1961:Q1); France (1978:Q1); Germany (1991:Q1); Italy (1980:Q1); Japan (1980:Q1); Netherlands (1977:Q1); Sweden (1980:Q1); United Kingdom (1960:Q1); United States (1960:Q1). We compute growth rates as year-over-year growth rates for each quarter. We define the long-run average growth rate as the average growth rate for 1960-2001, calculated using the annual data from Maddison (2003, Tables 1B, 2B, and 5B).

\section{Figure 2}

Labor Productivity: Annual data on GDP per hour worked obtained from the OECD productivity database (July 2005). The data for all countries span the years 1970-2004. We define the long-run average growth rate as the average growth rate for 1970-2004.

\section{Figures 3, 8, and 14}

Inflation: The sources for consumer price index data are listed above. We compute annual inflation rates by averaging annualized monthly growth rates. For booms ending prior to 1940, we define the long-run average growth rate as the average growth rate from the first available observation through 1939 (first available observations: Australia, 1902; Canada, 1911; France, 1872; Germany, 1924; Italy, 1871; Japan, 1871; Netherlands, 1882; Sweden, 1871; United Kingdom, 1871; United States, 1870). For booms ending after 1940, we define the long-run average growth rate as the average growth rate for 1947-2004.

\section{Figure 4}

Short-Term Interest Rate: Except as noted, monthly data on an overnight interest rate were downloaded from the International Financial Statistics (IFS) database of the International Monetary Fund. The IFS series identifier and description are listed below. The month of the first available observation is listed in parentheses.
Australia:
C193IM, short-term, weighted average of loans outstanding (1969:07)
Canada:
C156IM, money market (MMkt) overnight financing rate (1975:01)
France:
C132IM, MMkt opening rate: day-to-day loans against private bills (1965:01)
Germany:
C134IM, interbank overnight (1965:01)
Italy:
C136IM, 3-month interbank deposits, daily average (1971:01)
Japan:
C158IM, Tokyo overnight call money (1965:01)
Netherlands:
C138IM, MMkt rate on bankers' call loans (1965:01-1998:12)
Sweden:
C144IM, day-to-day interbank loans (1965:12)
United Kingdom: C112IM, interbank overnight offer rate (1972:01)
United States: C111IM, interbank overnight federal funds (1965:01)

\section{Figure 5}

Real Interest Rate: We compute the real short-term interest rate as the difference between the nominal short-term interest rate and CPI growth in the given month, and we compute CPI growth as the year-over- 
year change in the CPI for that month. Monthly data are from sources listed above. Monthly data on government security yields were downloaded from the IFS database. The IFS series identifier and description are listed below.

\section{Figure 6}

Interest Rate Term Spread: We compute the term spread as the difference between the yields on long-term government securities and the short-term interest rate used to construct Figure 4. Monthly data on government security yields were downloaded from the IFS database. The IFS series identifier and description are listed below.

$\begin{array}{ll}\text { Australia: } & \text { C193IB, 10-year government nonrebate bond yield } \\ \text { Canada: } & \text { C156IB, 10-or-more-year government bond yield to maturity } \\ \text { France: } & \text { C132IB, 5-or-more-year government bond yield to maturity } \\ \text { Germany: } & \text { C134IB, 3-or-more-year government \& agency bond yield, weighted average } \\ \text { Italy: } & \text { C136IB, 9-to-10-year government bond yield } \\ \text { Japan: } & \text { C158IB, yield to maturity of all ordinary government bonds } \\ \text { Netherlands: } & \text { C138IB, 10-year government bond yield: most recent bond } \\ \text { Sweden: } & \text { C144IB, 9-year government bond yield } \\ \text { United Kingdom: } & \text { C112IB, 20-year government bonds issued at par } \\ \text { United States: } & \text { C111IB, 10-year government bond yield at constant maturity }\end{array}$

\section{Figures 7 and 13}

Real GDP: Data are from Maddison (2003, Tables 1B, 2B, and 5B) for 1871-2001 and the OECD for 2001-04. For booms ending prior to 1940, we define the long-run average growth rate as the average growth rate for 1871-1939. For booms ending after 1940, we define the long-run average growth rate as the average growth rate for 1960-2001.

\section{Figures 9 and 10}

Commercial Paper Interest Rate: Monthly data were obtained from Global Financial Data, except as noted. There are no data for Australia, Canada, or Germany for the prewar period, and hence the medians plotted in the figure exclude these countries. The following lists the Global Financial Data series identifier and description for each country. Data availability is listed in parentheses.

France: $\quad$ IPFRAW, private discount rate (1922:01-1940:06)

Italy: $\quad$ IPITAW, private discount rate (1922:01-1939:09)

Japan: $\quad$ IPJPN3D, private bills 3-month discount rate (1900:01-1945:06)

Netherlands: $\quad$ IPNLDW, private discount rate/advances (1919:01-1940:05)

Sweden: $\quad$ IPSWEW, private discount rate (1926:01-1941:12)

United Kingdom: IPGBR3D, U.K. private discount rate (1900:01-2004:12)

United States: U.S. commercial paper interest rate (4- to 6-month), Federal Reserve Board, Banking and Monetary Statistics (1943, Table 120, pp. 450-51) (1919:01-1941:12)

\section{Figures 11 and 17}

Money Stock: Except as noted below, our data are for a broad money stock measure and come from Bordo et al. (2001, Appendix A). Recent data, which we obtained from Haver Analytics, are from the OECD. Data for euro area countries end in 1998. We do not include these countries in the calculation of median growth rates after 1998. For booms ending prior to 1940, we define the long-run average 
growth rate as the average growth rate for 1881-1939. For booms ending after 1940, we define the long-run average growth rate as the average growth rate for 1947-2004.

$\begin{array}{ll}\text { Australia: } & \text { Haver Analytics series C193FM3@OECDMEI, M3 (1998-2004) } \\ \text { Canada: } & \text { Haver Analytics series C156FM1@OECDMEI, M1 (1996-2004) } \\ \text { France: } & \text { Haver Analytics series C132FM3@OECDMEI, M3 (1990-1998) } \\ \text { Germany: } & \text { Haver Analytics series C134FM2@OECDMEI, M2 (1990-1998) } \\ \text { Italy: } & \text { Haver Analytics series C136FM2@OECDMEI, M2 (1996-1998) } \\ \text { Japan: } & \text { Haver Analytics series C158FM2@OECDMEI, M2 + CDs (1998-2004) } \\ \text { Netherlands: } & \text { Haver Analytics series C138FM3N@OECDMEI, M3 (1990-1998) } \\ \text { Sweden: } & \text { Haver Analytics series C144FM3N@OECDMEI, M3 (1996-2004) } \\ \text { United Kingdom: } & \text { Haver Analytics series C112FM4@OECDMEI, M4 (1998-2004) } \\ \text { United States: } & \text { Friedman and Schwartz (1963, Table A1, column 8) (1882-1959); } \\ & \text { Haver Analytics series C111FM2@OECDMEI, M2 (1960-2004) }\end{array}$

\section{Figures 12 and 18}

Real Money Stock: We compute real money stock growth as the difference between the growth rates of the nominal money stock and consumer price index. For booms ending prior to 1940, we define the long-run average growth rate as the average growth rate from the first available observation through 1939 (first available observations: Australia, 1902; Canada, 1911; France, 1881; Germany, 1926; Italy, 1881; Japan, 1881; Netherlands, 1882; Sweden, 1881; United Kingdom, 1881; United States, 1881). For booms ending after 1940, we define the long-run average growth rate as the average growth rate for 1947-2004.

\section{Figures 15 and 16}

Short-Term Interest Rate: Except as noted, monthly data on an overnight interest rate and/or Treasury bill rate were obtained from Global Financial Data. The following lists the Global Financial Data series identifier and description for each country. Data availability is listed in parentheses.
Australia:
ITAUS3D, 3-month T-bill yield (1928:07-2004:12)
Canada:
ITCAN3D, 3-month T-bill yield (1934:03-1956:12); IMCAND, overnight MMkt rate (1957:01-2004:12)
France: $\quad$ ITFRA3D, 3-month T-bill yield (1931:01-1936:04; 2002:01-2004:12);
IMFRAD, call money rate (1936:05-2001:12)
Germany: $\quad$ ITDEUM, 3-month T-bill yield (1953:01-1954:02; 2002:01-2004:12);
IMDEUD, call money rate (1954:03-2001:12)
Italy: $\quad$ ITITA3M, 3-month T-bill yield (1946:04-1978:05; 2002:01-2004:12);
IMITAD, interbank overnight rate (1978:06-2001:12)
Japan: IMJPND, overnight lending rate (1949:01-2004:12)
Netherlands: $\quad$ IMNLDD, overnight interbank rate (1929:01-2001:12);
ITNLDD, 3-month T-bill yield (2002:01-2004:12)
Sweden: $\quad$ ITSWE3D, 3-month T-bill yield (1955:01-1965:07);
IMSWED, overnight interbank rate (1965:08-2004:12)
United Kingdom: IMGBRD, overnight interbank rate (1945:12-2004:12)
United States: $\quad$ ITUSA3SD, 90-day T-bill secondary market (1920:01-1954:06);
overnight federal funds rate, Federal Reserve Bank of St. Louis FREDII database
(1954:07-2004:12) 